\title{
Exploring the vertical profile of atmospheric organic aerosol: comparing 17 aircraft field campaigns with a global model
}

\author{
C. L. Heald ${ }^{1}$, H. Coe ${ }^{2}$, J. L. Jimenez ${ }^{3}$, R. J. Weber ${ }^{4}$, R. Bahreini ${ }^{5}$, A. M. Middlebrook ${ }^{5}$, L. M. Russell ${ }^{6}$, M. Jolleys ${ }^{2}$, \\ T.-M. Fu ${ }^{7}$, J. D. Allan ${ }^{2,8}$, K. N. Bower ${ }^{2}$, G. Capes ${ }^{2}$, J. Crosier ${ }^{2}$, W. T. Morgan ${ }^{2}$, N. H. Robinson ${ }^{2}$, P. I. Williams ${ }^{2,8}$, \\ M. J. Cubison ${ }^{3, *}$, P. F. DeCarlo ${ }^{3, * *}$, and E. J. Dunlea ${ }^{3, * * *}$ \\ ${ }^{1}$ Department of Atmospheric Science, Colorado State University, Fort Collins, CO, USA \\ ${ }^{2}$ School of Earth, Atmospheric and Environmental Sciences, University of Manchester, UK \\ ${ }^{3}$ Department of Chemistry and Biochemistry, and CIRES, University of Colorado, Boulder, CO, USA \\ ${ }^{4}$ School of Earth and Atmospheric Science, Georgia Institute of Technology, Atlanta, GA, USA \\ ${ }^{5}$ ESRL Chemical Sciences Division, NOAA, Boulder, CO, USA \\ ${ }^{6}$ University of California - San Diego, La Jolla, CA, USA \\ ${ }^{7}$ Department of Atmospheric and Ocean Sciences and Laboratory for Climate and Ocean-Atmosphere Studies, Peking \\ University, Beijing, China \\ ${ }^{8}$ National Centre for Atmospheric Science, University of Manchester, UK \\ *now at: Tofwerk AG, Thun, Switzerland \\ ${ }^{* * *}$ now at: US EPA, Washington, DC, USA \\ **** now at: US National Academy of Sciences, Washington, DC, USA
}

Received: 29 August 2011 - Published in Atmos. Chem. Phys. Discuss.: 12 September 2011

Revised: 24 November 2011 - Accepted: 6 December 2011 - Published: 15 December 2011

\begin{abstract}
The global organic aerosol (OA) budget is highly uncertain and past studies suggest that models substantially underestimate observed concentrations. Few of these studies have examined the vertical distribution of OA. Furthermore, many model-measurement comparisons have been performed with different models for single field campaigns. We synthesize organic aerosol measurements from 17 aircraft campaigns from 2001-2009 and use these observations to consistently evaluate a GEOS-Chem model simulation. Remote, polluted and fire-influenced conditions are all represented in this extensive dataset. Mean observed OA concentrations range from $0.2-8.2 \mu \mathrm{g} \mathrm{sm}^{-3}$ and make up 15 to $70 \%$ of non-refractory aerosol. The standard GEOSChem simulation reproduces the observed vertical profile, although observations are underestimated in 13 of the 17 field campaigns (the median observed to simulated ratio ranges from 0.4 to 4.2 ), with the largest model bias in anthropogenic regions. However, the model is best able to capture the observed variability in these anthropogenicallyinfluenced regions $\left(R^{2}=0.18-0.57\right)$, but has little skill in remote or fire-influenced regions. The model bias increases as a function of relative humidity for 11 of the
\end{abstract}

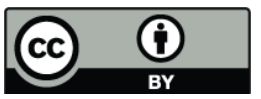

Correspondence to: C. L. Heald (heald@atmos.colostate.edu) campaigns, possibly indicative of missing aqueous phase SOA production. However, model simulations of aqueous phase SOA suggest a pronounced signature in the midtroposphere $(2-6 \mathrm{~km})$ which is not supported in the observations examined here. Spracklen et al. (2011) suggest adding $\sim 100 \mathrm{Tg} \mathrm{yr}^{-1}$ source of anthropogenically-controlled SOA to close the measurement-model gap, which we add as anthropogenic SOA. This eliminates the model underestimate near source, but leads to overestimates aloft in a few regions and in remote regions, suggesting either additional sinks of OA or higher volatility aerosol at colder temperatures. Sensitivity simulations indicate that fragmentation of organics upon either heterogeneous or gas-phase oxidation could be an important (missing) sink of OA in models, reducing the global SOA burden by $15 \%$ and $47 \%$ respectively. The best agreement with observations is obtained when the simulated anthropogenically-controlled SOA is increased to $\sim 100 \mathrm{Tg} \mathrm{yr}^{-1}$ accompanied by either a gas-phase fragmentation process or a reduction in the temperature dependence of the organic aerosol partitioning (by decreasing the enthalpy of vaporization from $42 \mathrm{~kJ} \mathrm{~mol}^{-1}$ to $25 \mathrm{~kJ} \mathrm{~mol}^{-1}$ ). These results illustrate that models may require both additional sources and additional sinks to capture the observed concentrations of organic aerosol.

Published by Copernicus Publications on behalf of the European Geosciences Union. 


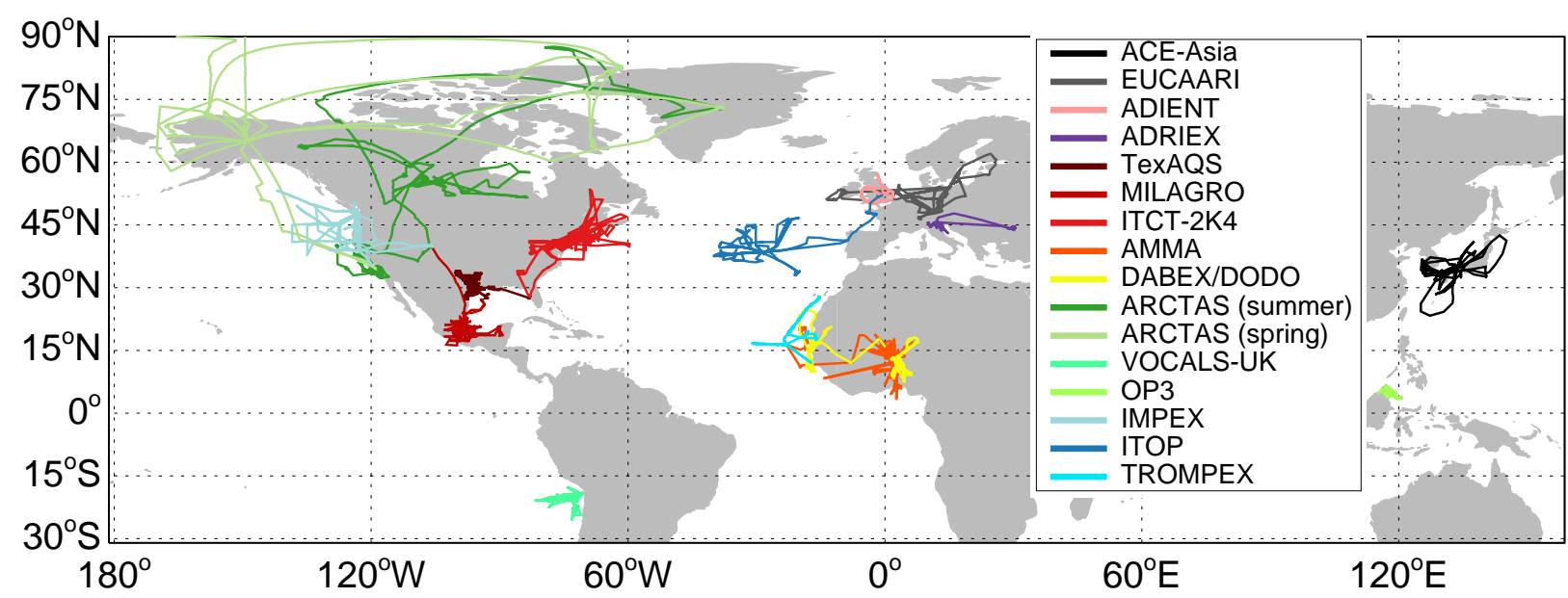

Fig. 1. Flight tracks for the 17 aircraft field campaigns examined here. See Table 1 for dates and measurement details.

\section{Introduction}

Fine aerosols contain a substantial fraction of organic material over much of the world (Zhang et al., 2007). Despite this, the sources and budget of these particles are poorly understood. While models have been unable to reproduce the magnitude and variability of observed concentrations of organic aerosol (OA) in many regions (Heald et al., 2005; Heald et al., 2006; de Gouw et al., 2005; Volkamer et al., 2006; Johnson et al., 2006; Chung and Seinfeld, 2002; Hodzic et al., 2009; Kleinman et al., 2008), they perform better in clean regions (Capes et al., 2009; Chen et al., 2009; Dunlea et al., 2009; Slowik et al., 2010). Few of these comparisons have explored the vertical extent and distribution of OA. Knowledge of the vertical distribution of $\mathrm{OA}$ is required to estimate the global budget and the impact of OA on climate and can provide key insight into OA evolution and lifetime. Previous observational evaluations of our understanding of OA formation and processing have been performed with a suite of different model types, spanning the scale of constrained box models through to global 3-D models, with different model parameters and complexity. Furthermore, most studies use a model to interpret observations from a single field campaign or surface network. It is therefore imperative to integrate these individual studies into a picture of generic model weaknesses which could be used to inform future experimental investigations. Our objectives here are therefore twofold: to synthesize the largest single set of observations of OA from aircraft campaigns to examine the vertical distribution of these particles in diverse environments and to use these to consistently investigate OA loading in a global model.

Organic aerosol is traditionally thought to be either directly emitted as primary organic aerosol (POA) or formed from the low-volatility oxidation products of gas-phase precursors as secondary organic aerosol (SOA). Recent work on the volatility of emitted particles has blurred the distinctions between these categories, with oxidation of primary emissions as well as previously unrecognized semi-volatile and intermediate volatility compounds (S/IVOC), producing an additional source of SOA (Robinson et al., 2007; Jimenez et al., 2009; de Gouw et al., 2011). These concepts have been adopted in many recent model studies, however limited laboratory constraints on this system have required the application of a considerable degree of chemical intuition and conjecture in implementation (Pye and Seinfeld, 2010; Murphy and Pandis, 2009; Lane et al., 2008;Farina et al., 2010). Furthermore, the discrepancy between models and observations has motivated a re-examination of chamber experiments, leading to revisions of previously estimated SOA yields (Shilling et al., 2008; Ng et al., 2007b), the identification of new SOA precursors (Kroll et al., 2005; Volkamer et al., 2009; Lim and Ziemann, 2009) and the recognition of the impact of environmental conditions on yields (e.g. RH, acidity, nitrogen oxide levels) ( $\mathrm{Ng}$ et al., 2007a; Iinuma et al., 2004; Surratt et al., 2007). Both laboratory and field studies have also suggested that aqueous processing of organics may be an important additional pathway for SOA formation (Lim et al., 2005; Carlton et al., 2006; Sorooshian et al., 2007a; Volkamer et al., 2007). Model descriptions of OA may include any combination of the above processes with varying complexity. Thus, a bottom-up modeling approach to investigating the organic aerosol budget is highly challenging and poorly constrained.

Field observations of ambient organic aerosol therefore play the critical role of arbiter of model fidelity. While the examination of OA concentrations at surface sites in the United States by Chung and Seinfeld (2002) was indicative of model bias, this became more evident during highly instrumented field campaigns that followed, where the evolution of OA could be tracked with high time-resolution (thus 
Table 1. Airborne measurements of organic aerosol (chronological).

\begin{tabular}{|c|c|c|c|c|}
\hline Campaign (Aircraft) & Location (Dates) & Technique \& Reference & $\begin{array}{l}\text { Mean (Standard Deviation) } \\
\text { of observed OA } \\
\text { Concentrations } \\
\mu \mathrm{g} \mathrm{sm}^{-3}\end{array}$ & Regional Class \\
\hline ACE-Asia (C-130) & NW Pacific, near Japan (30 Mar-4 May 2001) & Teflon filters + FTIR (Maria et al., 2004) & $8.2(6.2)$ & Pollution (mid-latitude) \\
\hline ITCT-2K4 (NOAA P3) & E North America (5 Jul-15 Aug 2004) & PILS WSOC (Sullivan et al., 2006) & $4.3(4.7)$ & Pollution/Fire (mid-latitude) \\
\hline ITOP (BAE-146) & Azores (12 July-3 Aug 2004) & Q-AMS (Lewis et al., 2007) & $0.6(2.0)$ & Remote (mid-latitude) \\
\hline ADRIEX (BAE-146) & $\begin{array}{l}\text { N Italy; Adriatic \& } \\
\text { Black Sea (27 Aug-6 Sep 2004) }\end{array}$ & Q-AMS (Crosier et al., 2007) & $3.5(2.8)$ & Pollution (mid-latitude) \\
\hline $\begin{array}{l}\text { DABEX (BAE-146) } \\
\text { DODO (BAE-146) }\end{array}$ & $\begin{array}{l}\text { W Africa (13 Jan-1 Feb 2006) } \\
\text { W Africa (3-16 Feb 2006) }\end{array}$ & $\begin{array}{l}\text { Q-AMS (Capes et al., 2008) } \\
\text { Q-AMS (Capes et al., 2008) }\end{array}$ & $5.8(8.3)$ & $\begin{array}{l}\text { Fire (tropics) } \\
\text { Fire (tropics) }\end{array}$ \\
\hline MILAGRO (C130) & Mexico City (4-31 Mar 2006) & HR-ToF-AMS (DeCarlo et al., 2008) & $5.9(14.2)$ & Pollution/Fire (sub-tropics) \\
\hline IMPEX (C130) & $\begin{array}{l}\text { W North America \& } \\
\text { E Pacific (17 April-15 May 2006) }\end{array}$ & HR-ToF-AMS (Dunlea et al., 2009) & $0.7(1.0)$ & Remote + aged (mid-latitude) \\
\hline AMMA (BAE-146) & W Africa (20 Jul-25 Aug 2006) & Q-AMS (Capes et al., 2009) & $1.5(3.4)$ & Fire (tropics) \\
\hline TexAQS (NOAA P3) & Texas (11 Sep-13 Oct 2006) & C-ToF-AMS (Bahreini et al., 2009) & $4.3(2.8)$ & Pollution (mid-latitudes) \\
\hline ADIENT (BAE-146) & EU/Atlantic (18 Dec 2007-25 Sep 2008) & C-ToF-AMS (Morgan et al., 2010) & $2.1(1.8)$ & Pollution (mid-latitudes) \\
\hline EUCAARI (BAE-146) & N EU (6-22 May 2008) & C-ToF-AMS (Morgan et al., 2010) & $2.8(2.2)$ & Pollution (mid-latitudes) \\
\hline ARCTAS (DC-8) & $\begin{array}{l}\text { Arctic/N EU (1-20 April 2008) } \\
\text { (18 June-13 July 2008) }\end{array}$ & HR-ToF-AMS (Cubison et al., 2011) & $\begin{array}{l}1.1(3.2) \\
6.4(19.6)\end{array}$ & Fire (high latitudes) \\
\hline OP3 (BAE-146) & Borneo (10-20 Jul 2008) & C-ToF-AMS (Robinson et al., 2011) & $0.7(1.8)$ & Remote (tropical) \\
\hline VOCALS-UK (BAE-146) & Eastern S Pacific (27 Oct-13 Nov 2008) & C-ToF-AMS (Allen et al., 2011) & $0.2(0.2)$ & Remote (tropical) \\
\hline TROMPEX (BAE-146) & Cape Verde (8-10 Sep 2009) & C-ToF-AMS & $0.4(1.3)$ & Remote (tropical) \\
\hline
\end{tabular}

*Fourier Transform Infrared Spectrometer (FTIR), Particle Into Liquid Sampler (PILS), Water Soluble Organic Carbon (WSOC), Quadrupole Aerosol Mass Spectrometer (Q-AMS), High Resolution Time-of-Flight (HR-ToF), Compact Time-of-Flight (C-ToF).

allowing correlation with gas-phase tracers) and some chemical resolution (e.g. Volkamer et al., 2006; de Gouw et al., 2005). Airborne observations supply an additional vertical dimension which can be used to differentiate surface source influences and injection/production aloft. The vertical distribution of OA is also a key indicator of atmospheric lifetime and export efficiency, and ultimately can be used to characterize the global budget of these particles (Heald et al., 2010). The first airborne observations of OA were obtained in the Caribbean during PELTI in 2000 (Maria et al., 2002). With numerous airborne campaigns around the world over the past decade, we are now in a position to examine the top-down constraints that these campaigns offer on the distribution and processing of OA.

\section{Description of observations}

This study integrates observations of atmospheric composition taken during 17 aircraft field campaigns which took place between 2001 and 2009. This is the most spatially comprehensive suite of in situ observations of organic aerosol collected to date. Figure 1 shows the flight tracks for these campaigns (Fig. S1 shows the flight tracks colored by altitude and observed OA concentrations). The timing and primary references for each campaign are listed in Table 1. All but one of these campaigns took place in the Northern Hemisphere, with a particularly dense cover- age of the northern mid-latitudes. However, remote, polluted and fire-influenced conditions are all represented in this dataset. The measurements also preferentially characterize spring/summer conditions, although all seasons are represented in the dataset. Aerosol concentrations were measured using an Aerodyne Aerosol Mass Spectrometer (AMS) (Jayne et al., 2000; Canagaratna et al., 2007) in 15 of the 17 campaigns. The exceptions are the Fourier Transform Infrared Spectroscopy (FTIR) filter measurements during ACE-Asia (Maria et al., 2003) and the Particle-Into-Liquid Sampler (PILS) measurements of water soluble organic carbon (WSOC) during ITCT-2K4 (Sullivan et al., 2006). These measurements all nominally represent sub-micron aerosol, although transmission efficiencies may differ between instrumentation. Uncertainty on the AMS species mass concentrations is estimated $\sim 30-35 \%$ (Bahreini et al., 2009). We refer readers to the references in Table 1 for details on specific instrumentation and on the data analysis procedures.

All aerosol concentrations are given here as mass concentrations at standard temperature and pressure (STP: $298 \mathrm{~K}$, $1 \mathrm{~atm}$ ) denoted as $\mu \mathrm{g} \mathrm{sm}^{-3}$. Observations are also reported as 1-min averages for all campaigns, with the exception of ACE-Asia observations which are reported on the coarser native time scale of the filter samples. Observations are gridded to the model grid resolution when compared with model simulations in Sects. 4, 5 and 6. In this case, observations that fall within a given grid box during a model time step are averaged. 
A number of these campaigns were significantly influenced by either local or transported biomass burning emissions, mainly from wildfires. We use observations of acetonitrile measured via Proton Transfer Reaction Mass Spectrometry (PTR-MS), where available, to identify this influence (7 campaigns: ITCT-2K4, TexAQS, MILAGRO, ARCTAS spring and summer, IMPEX and AMMA) (Murphy et al., 2010; Karl et al., 2009; de Gouw et al., 2006; Warneke et al., 2006). This relationship is generally characterized by a cluster of points with a branch of coincidentally high OA and acetonitrile observations from in-plume measurements (Fig. S2). As previously shown, the ITCT2K4 observations were heavily influenced by wide-spread fires in Alaska and Northern Canada in 2004 (Heald et al., 2006). Aircraft sampled fire plumes transported from the boreal regions, including Siberia and North America, during both the spring and summer ARCTAS campaigns in 2008 as well (Singh et al., 2011; Wang et al., 2011). The AMMA campaign in Western Africa was coincident with the peak in Southern Hemisphere agricultural burning (Reeves et al., 2010). As a result, air masses sampled in Western Africa included contributions from aged and elevated fire plumes (Murphy et al., 2010). Biomass burning was one of several sources which led to elevated aerosol concentrations in Mexico City during MILAGRO (DeCarlo et al., 2008). Similarly, local biomass burning occasionally influenced TexAQS observations, but was not a dominant source (Bahreini et al., 2009). OA observations from IMPEX, a campaign which is relatively devoid of biomass burning influence (Dunlea et al., 2009), show little correlation with acetontrile (Fig. S2). We see a strong relationship between $\mathrm{OA}$ and acetonitrile for campaigns influenced by boreal fire activity. Vigorous vertical mixing, characteristic of the tropics, diluted fire plumes during the AMMA campaign, but the relationship between $\mathrm{OA}$ and acetronitrile remains. The cluster of very high OA concentrations measured during AMMA were obtained during a circuit of Lagos and are not fire-dominated. For the six campaigns with identifiable fire influence, where noted, we identify the most intense fire plumes as those cases where acetonitrile exceeds the 80th percentile of observed concentrations (marked as dotted lines in Fig. S2, 80th percentile values vary between 135-289 ppt). Observations made during January and February in Western Africa during DABEX and DODO are also dominated by fire activity (Capes et al., 2008), but measurements of acetonitrile concentrations are not available for these campaigns.

Figure 2a shows the range of OA concentrations measured across all 17 campaigns (here and in what follows the DABEX and DODO campaign measurements are merged for simplicity). The observed variability may reflect not only the environment, but also campaign objectives, in terms of relative efforts to sample background and concentrated plumes. Mean concentrations lie between 0.2 to $8.2 \mu \mathrm{g} \mathrm{sm}^{-3}$ (means and standard deviations for each campaign are listed in Table 1). The lowest OA concentrations (with means less than $1 \mu \mathrm{g} \mathrm{sm}^{-3}$ ) are reported for ITOP and IMPEX over the Northern Atlantic and Pacific, VOCALS-UK in the subtropical Pacific off of Chile, TROMPEX off of equatorial Africa, and the OP3 campaign off of Borneo. These campaigns constitute our "remote" sampling dataset, grouped to the right of the figure. OA concentrations during the springtime ARCTAS campaign are also quite low, and sampling over the Arctic could certainly be considered remote, but these observations are influenced by boreal fire activity (see above) and they will therefore be counted in our biomass burning dataset along with DABEX, DODO, AMMA, and ARCTAS (summer). The remaining campaigns: ACE-Asia, TexAQS, ADIENT, EUCAARI, and ADRIEX, are primarily influenced by anthropogenic outflow. MILAGRO and ITCT$2 \mathrm{~K} 4$ are heavily influenced by both biomass burning and pollution outflow. Concentrations reported during DABEX, ARCTAS (summer) and MILAGRO exhibit the largest variability, reflecting a mixing of clean air with plumes. Figure $2 \mathrm{~b}$ confirms these classifications, demonstrating low sulfate concentrations for the remote and biomass burning datasets. Mean sulfate concentrations exceed $1 \mu \mathrm{g} \mathrm{sm}^{-3}$ in all of the anthropogenically-influenced regions.

Figure 2c shows that OA makes up $15-70 \%$ on average of the sub-micron non-refractory aerosol mass (total of OA, sulfate, nitrate and ammonium) measured across these campaigns. Contributions can be as low as $2 \%$ and as high as $95 \%$ for individual 1-min measurements. Campaigns characterized with the lowest mean OA fractions include the clean IMPEX, TROMPEX and VOCALS-UK observations, the remote springtime ARCTAS measurements and the Northern European ADIENT measurements where the ammonium nitrate fraction was enhanced. For ACE-Asia, DABEX and ARCTAS (summer) more than $2 / 3$ on average of the aerosol mass is made up of OA. Two of these campaigns are part of the biomass burning class we have defined.

We do not include the measurements made in summer of 2000 during the PELTI experiment in our analysis (Maria et al., 2002), primarily because sampling did not extend beyond $4 \mathrm{~km}$ altitude. However we note here for comparison that concentrations in this campaign ranged from 0.8 to $4.0 \mathrm{~g} \mathrm{sm}^{-3}$, with decreasing concentration with altitude.

In what follows, we use the spatial distributions of the observed organic aerosol concentrations across all these regions to investigate loading and the potential contribution of different sources and sinks as represented in the GEOS-Chem model. The investigation of timescales of formation and processing requires a more detailed analysis of individual events and environments and is beyond the scope of this work.

\section{Model description}

In this study we use the global chemical transport model GEOS-Chem (www.geos-chem.org) to simulate aerosol concentrations for each aircraft campaign. The GEOSChem coupled aerosol-oxidant simulation includes $\mathrm{H}_{2} \mathrm{SO}_{4}$ - 
a)

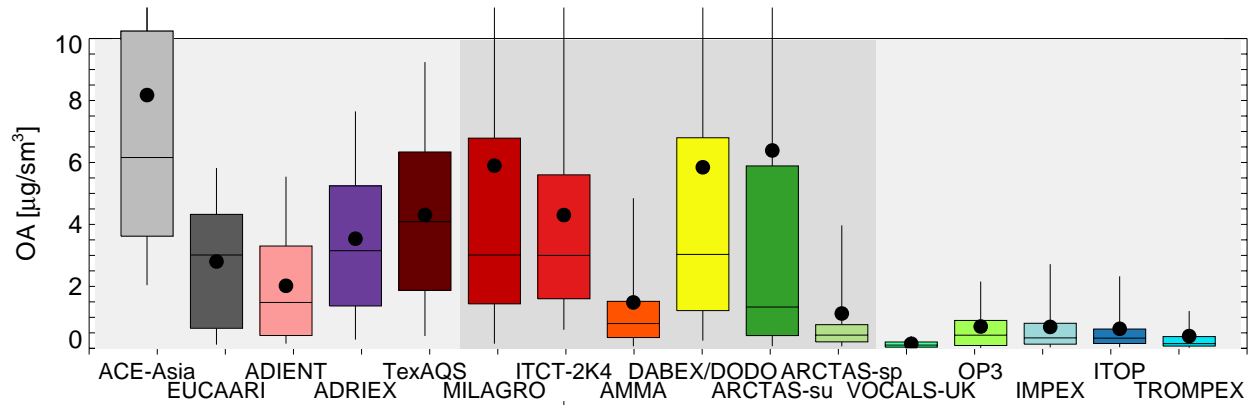

b)

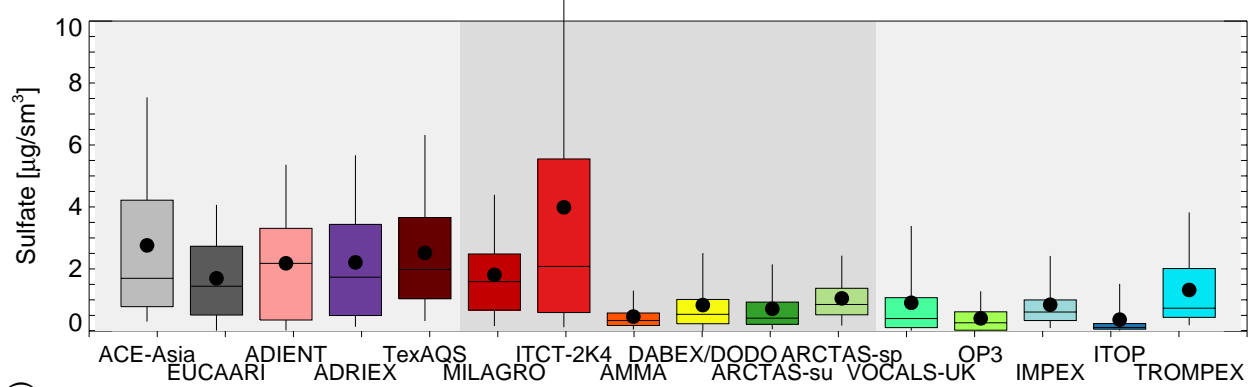

C)

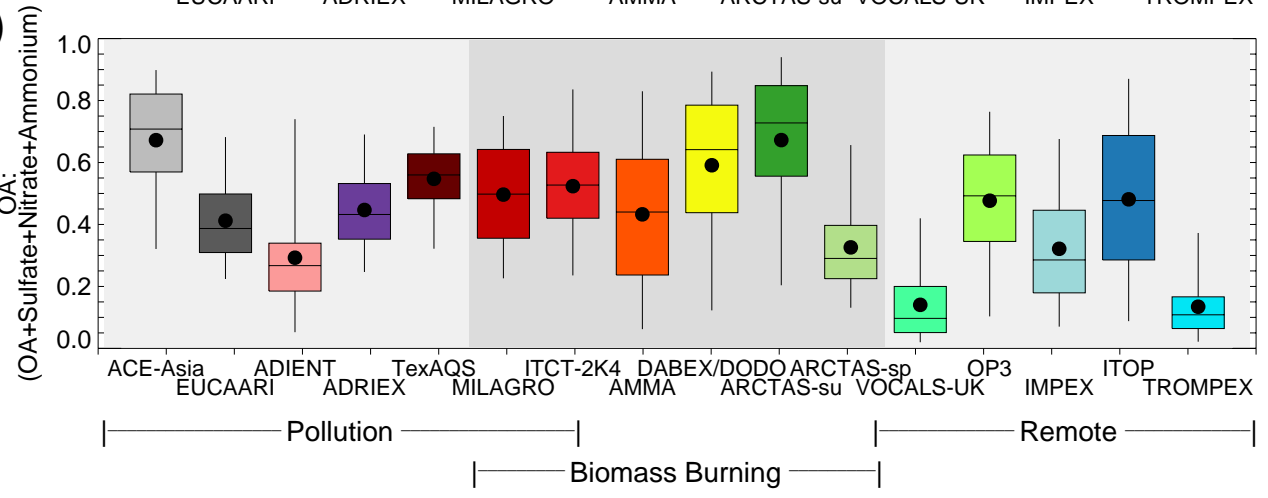

Fig. 2. Box and whisker plots of (a) the observed OA concentrations, (b) the observed sulfate concentrations and (c) the observed fraction of non-refractory fine aerosol (OA+sulfate+nitrate+ammonium) that is made up of OA for each field campaign. Campaigns are grouped in 3 types, labeled across the bottom. Means of the 1-min averaged data are shown as a solid dot, median as a horizontal line. The boxes denote 25th and 75th percentile, whiskers denote 5th and 95th percentile.

$\mathrm{HNO}_{3}-\mathrm{NH}_{3}$ aerosol thermodynamics coupled to an ozone$\mathrm{NO}_{\mathrm{x}}$-hydrocarbon-aerosol chemical mechanism (Park et al., 2004). The model scheme also includes black carbon (Park et al., 2003), organic aerosol (details below), sea salt aerosol (Alexander et al., 2005), and soil dust (Fairlie et al., 2007). Results are shown with v8-03-01 of the model at $2^{\circ} \times 2.5^{\circ}$ horizontal resolution driven by assimilated meteorology from the NASA Global Modeling and Assimilation Office (GMAO). The simulations use GEOS-5 meteorology for 2004-2009, and GEOS-4 meteorology in 2001 when the GEOS-5 product is not available. Vertical resolution is 47 levels for GEOS-5 and 30 levels for GEOS4 from the surface to $\sim 0.01 \mathrm{hPa}$ (both degraded for computational effiiency from 72 and 55 levels respectively). The model is sampled for the time and location of the aircraft for each campaign, thus achieving a best match to meteorological conditions and emissions.
Our objective here is to use one consistent organic aerosol simulation across a suite of field data from multiple years. We use the standard configuration of GEOS-Chem and do not include recent developments aimed at capturing the potential additional source of organic aerosol from semivolatile and intermediate volatility compounds (Pye and Seinfeld, 2010). Our simulations thus represent a baseline scheme of nonvolatile primary organic aerosol (POA) and semi-volatile secondary organic aerosol (SOA). POA sources include fossil fuel from Bond et al. (2007) biofuel from Yevich and Logan (2003) and year-specific monthly-mean biomass burning from the GFED2 inventory (with the exception of 2009 for which year-specific emissions are not available and climatology is employed) (van der Werf et al., 2006). We assume that $50 \%$ of POA emitted from combustion sources is hydrophobic with a 1.2 day e-folding conversion from hydrophobic to hydrophilic to account for aerosol aging and 
Table 2. Annual global organic aerosol sources in GEOS-Chem simulation for year 2008 .

\begin{tabular}{ll}
\hline TYPE & $\begin{array}{l}\text { SOURCE } \\
\left(\mathrm{Tg} \mathrm{yr}^{-1}\right)\end{array}$ \\
\hline Fossil Fuel POA & 6.1 \\
Biofuel POA & 12.6 \\
Biomass Burning POA & 36.6 \\
Biogenic SOA (BSOA) & 23.4 \\
Anthropogenic SOA (ASOA) & 3.1 \\
\hline TOTAL & 81.8 \\
\hline
\end{tabular}

mixing (Park et al., 2003). We apply a ratio of 2 to simulated organic carbon $(\mathrm{OC})$ concentrations to account for noncarbon mass in POA (Turpin and Lim, 2001;Aiken et al., 2008). Although this ratio is too high for POA as emitted, it reflects the effect of aging and oxygen gain in the OA:OC for simplicity. The SOA simulation uses a 2-product model scheme based on Chung and Seinfeld (2002) and includes biogenic (monoterpenes, sesquiterpenes, isoprene) and anthropogenic (aromatics) precursors and their updated gasphase yields based on smog chamber studies, as most recently described by Henze et al. (2008). This framework is described as follows:

$$
\begin{aligned}
\text { VOC }+ \text { oxidant } & \rightarrow \alpha_{1} \mathrm{SOG}_{1} \leftrightarrow \mathrm{SOA}_{1} \\
& \rightarrow \alpha_{2} \mathrm{SOG}_{2} \leftrightarrow \mathrm{SOA}_{2}
\end{aligned}
$$

Where SOG represents the secondary organic gases, produced in proportion to the mass-based stoichiometric coefficients $(\alpha)$, and in equilibrium with the particle phase (SOA), as a function of the partitioning coefficients or saturation vapor pressures. Note that the initial products of aromatic oxidation are allowed to react with $\mathrm{HO}_{2}$ or $\mathrm{NO}$ before partitioning to the particle phase, with different yield parameters for the associated high and low $\mathrm{NO}_{\mathrm{x}}$ regimes and the formation of non-volatile $\mathrm{SOA}$ under low $\mathrm{NO}_{\mathrm{x}}$ conditions (Henze et al., 2008).

As in Henze et al. (2008) we describe the temperature dependence of partitioning coefficients with an enthalpy of vaporization $\left(\Delta \mathrm{H}_{\mathrm{vap}}\right)$ of $42 \mathrm{~kJ} \mathrm{~mol}^{-1}$. A sensitivity simulation with $\Delta \mathrm{H}_{\mathrm{vap}}=25 \mathrm{~kJ} \mathrm{~mol}^{-1}$ is presented in Sect. 6. Biogenic VOC emissions are calculated interactively based on the MEGAN2 emission scheme (Guenther et al., 2006), whereas anthropogenic VOC emissions are specified following the GEIA inventory (Wang et al., 1998). The global OA sources total $82 \mathrm{Tg} \mathrm{yr}^{-1}$ for 2008 and are shown by category in Table 2. In Sect. 6 we also discuss aqueous-phase production of SOA from glyoxal and methylglyoxal simulated using the empirical irreversible uptake scheme of Fu et al. (2008). This source is not otherwise included in our GEOS-Chem simulations.
Global anthropogenic $\mathrm{SO}_{2}$ sources follow EDGAR 3.2 (Olivier et al., 2001) and are over-written by regional inventories where available, including the European Monitoring and Evaluation Programme (EMEP) inventory for Europe (Vestreng and Klein, 2002), the EPA National Emission Inventory (NEI) for 2005 for the US (EPA, 2008), the Criteria Air Contaminants (CAC) inventory from Environment Canada (http://www.ec.gc.ca/pdb/cac/cac_home_e. cfm), BRAVO for Mexico (Kuhns et al., 2005) and Streets et al. (2006) for Asia. Anthropogenic emissions are scaled for the year of simulation up to 2006, and held constant thereafter. Year-specific biomass burning emissions are from the same GFED2 inventory as OA. Ship emissions of $\mathrm{SO}_{2}$ are specified according to the pre-mission ARCTAS inventory based on the work of Eyring et al. (2005a, b). $\mathrm{SO}_{2}$ is also emitted from both eruptive and non-eruptive (continuous degassing) volcanoes following the AEROCOM inventory from 1985-2007 (Diehl, 2009). The sulfur source from DMS oxidation is described by Park et al. (2004).

Wet deposition of soluble aerosols and gases follows the scheme of Liu et al. (2001) including contributions from scavenging in convective updrafts, rainout, and washout. Gas-phase organics (SOG) in equilibrium with SOA are assumed to be highly soluble $\left(\mathrm{H}=1 \times 10^{5} \mathrm{M} \mathrm{atm}^{-1}\right)$. An $80 \%$ scavenging efficiency is assumed for SOA based on Chung and Seinfeld (2002). Increasing this efficiency to $100 \%$ (mimicking sulfate removal efficiency) reduces the global SOA burden by only $3 \%$ in a 2008 sensitivity simulation. Dry deposition follows a standard resistance-in-series model (Wesely, 1989). Wet removal constitutes $90 \%$ of the total deposition of SOA. Fisher et al. (2011) show that simulated wet removal of inorganic aerosol in GEOS-Chem agrees well with deposition measurements in the United States, Europe and Asia. Thus, while uncertainties on organic aerosol deposition remain large, given the unbiased simulation of inorganic aerosol removal in GEOS-Chem and our assumptions of highly soluble organics, our OA removal is most likely to be unbiased, or at worst overestimated.

Previous versions of this model have been compared against organic aerosol observations from surface networks in the United States, demonstrating a low bias (Liao et al., 2007; Park et al., 2003; van Donkelaar et al., 2007). ACEAsia airborne measurements were significantly underestimated by an early version of the model which did not include SOA formation from isoprene and aromatics (Heald et al., 2005). The model underestimate of OA during ITCT2K4 was more modest, however it was shown that the model had little skill in reproducing the variability of observed OA concentrations (Heald et al., 2006). Similarly, the model simulation of the surface observations from the Amazon during the AMAZE-08 campaign was not significantly biased (Chen et al., 2009). These studies were performed with different model versions and importantly, different meteorology than the results shown here. 


\section{Vertical profile of Organic Aerosol}

Figure 3 shows the mean vertical profile of OA measured for each field campaign compared with the baseline GEOSChem simulation. Simulated contributions from hydrophobic POA $\left(\mathrm{POA}_{o}\right)$, hydrophilic POA $\left(\mathrm{POA}_{i}\right)$ and SOA are shown separately. Many of these campaigns do not represent a uniform sampling of the region, but rather a "plume chasing" approach that skews the observations towards high values. Coarse grid scale global models cannot reproduce concentrated plumes (Rastigejev et al., 2010), thus the median of the observations (also shown), which is unaffected by these extreme plumes, is likely the "best" test of model performance. While Fig. 3 shows the mean of the simulated concentrations, the model means and medians are largely interchangeable here. The standard model underestimates observed OA concentrations at virtually all altitudes, in all environments, although the profile shape is reproduced in most regions. This comparison will be discussed further in Sect. 5 .

Generally, organic aerosol concentrations peak in the boundary layer and decline with altitude, reflecting the role of dilution and removal (e.g. TexAQS and ADRIEX). Biomass burning perturbs this profile, with elevated layers aloft through the free troposphere. Where available, we use observations of acetonitrile to filter out only the most intense fire plumes (see Sect. 2) which we do not expect the model to capture; the resulting means are shown as thin lines. It is important to note that this retains the regional ("diffuse") biomass burning influence on OA concentrations. This biomass burning plume filtering removes enhanced OA layers from 3-4 km during ITCT-2K4 and ARCTAS (spring) and reduces the concentrations at these altitudes during MILAGRO. OA concentrations from the surface up to $5 \mathrm{~km}$ during ARCTAS (summer) are more than halved when these plumes are removed. Removal of fire plumes also reduces OA concentrations throughout the troposphere during TexAQS and AMMA. The filtered mean profiles strongly resemble the median profiles, indicating that this filtering largely removes the high tail of the distribution of observed OA concentrations. The ratio of POA to SOA in polluted regions for the model is larger than 1 , which contrasts with ratios much smaller than 1 in observations in aged polluted air, e.g. (de Gouw and Jimenez, 2009). This suggests that SOA (including oxidized SOA from S/IVOC) in the polluted regions in the model may be underestimated, and/or that POA is overestimated by assuming it is entirely non-volatile. Asia may be an exception to this. Fu et al. (2011) suggest that Chinese primary anthropogenic emissions of OA are severely underestimated in bottom-up emission inventories. This may contribute to the discrepancy observed during ACE-Asia in the boundary layer, but cannot explain elevated free tropospheric concentrations of OA.

The OA profile observed during ACE-Asia is relatively unique among the datasets with uniformly high concentra- tions in the free troposphere and no evident biomass burning influence (Heald et al., 2005).

The OA profile for our "remote" dataset is far more uniform, with low concentrations reported throughout the troposphere. The bulk of these measurements are taken over the ocean and are therefore not strongly influenced by local continental emissions. Lowest altitude measurements $(<$ $1 \mu \mathrm{g} \mathrm{sm}^{-3}$ ) are consistent with ship-based observations of OA, likely of marine origin (Lapina et al., 2011). The low OA concentrations do not indicate substantial production of OA during long range transport, consistent with the hypothesis of Peltier et al. (2007) and Dunlea et al. (2009) that sustained net production of OA does not occur in aged pollution advected over ocean basins unlike the continued production of sulfate (Brock et al., 2004).

Figure 4 shows the observed and simulated profiles of sulfate for comparison. The model generally captures the magnitude and shape of the profile of sulfate. This provides some additional support for the accuracy of the wet removal scheme in GEOS-Chem. The model significantly underestimates sulfate observed near Borneo during OP3. This suggests that local emissions in the region, including continental, ship or DMS, are underestimated. Robinson et al. (2011) use backtrajectories to ascribe the sulfate source during OP3 to be off-island. The simulation is not improved with the use of an alternate ship emission inventory from the International Comprehensive Ocean-Atmosphere Data Set (ICOADS) (Wang et al., 2008). Sulfate exceeds OA concentrations in several of the remote regions, but as Fig. 3c suggests, OA dominates aerosol composition for the majority of campaigns. Figure 5 shows that the ratio of mean observed OA to mean observed sulfate ranges almost three orders of magnitude (from 0.11-63) across different regions, an even larger range than that reported by Heald et al. (2010) for the Zhang et al. (2007) surface observations (0.3 to 7.0). Remote sites are the only regions where observed sulfate concentrations exceed OA levels (Figs. 4 and 5). The variability in this ratio demonstrates that scaling the sulfate source to estimate the OA budget as in (Hallquist et al., 2009; Goldstein and Galbally, 2007) can provide only a very coarse, and regionally inaccurate, estimate. Indeed, uniformity in this ratio would be surprising given the diversity in sources and formation pathways for these two different species. The observed sulfate to organic aerosol relationship is shown in Fig. S3, with high overall correlation in anthropogenic environments, but a diversity of influences apparent in most datasets. Given the low bias in simulated OA, the model generally does not exceed OA to sulfate ratios of $\sim 10$, and is not as variable as observed.

\section{Model Evaluation Metrics}

Figure 6 shows both the ratio and difference between observed and simulated OA concentrations for all 17 field 

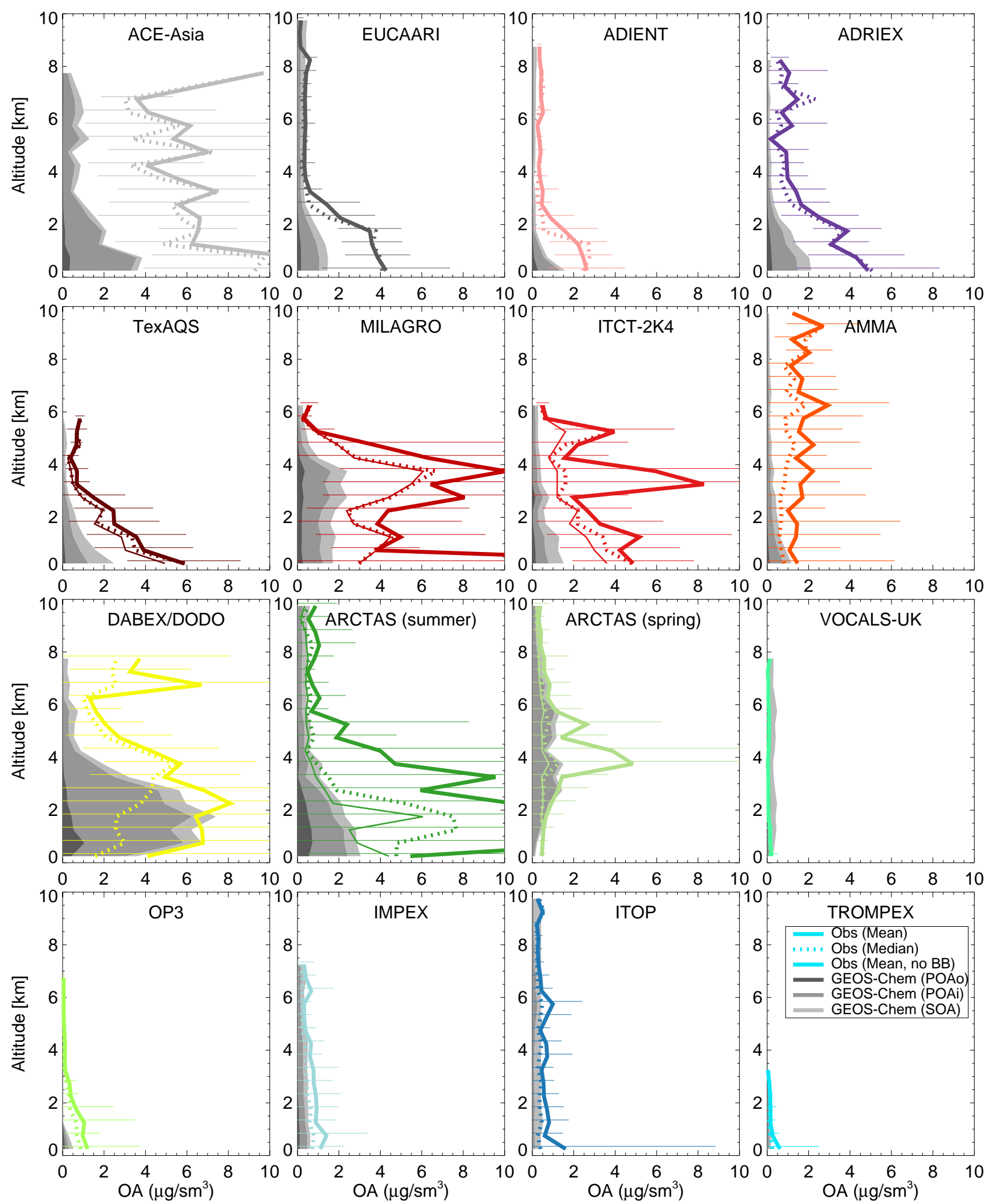

Fig. 3. Mean vertical profile of organic aerosol for 17 field campaigns (color, solid) with the mean GEOS-Chem simulation shown in grey. Model contributions from hydrophobic POA (dark grey), hydrophilic POA (medium grey) and SOA (light grey) are shown. Median observed values at each altitude are shown as dotted lines. Mean observed values with biomass burning plumes removed (see text) are shown as thin colored lines. The standard deviation of the binned observations at each $0.5 \mathrm{~km}$ interval are also shown. The model simulation is sampled for the dates and locations of each aircraft campaign. 

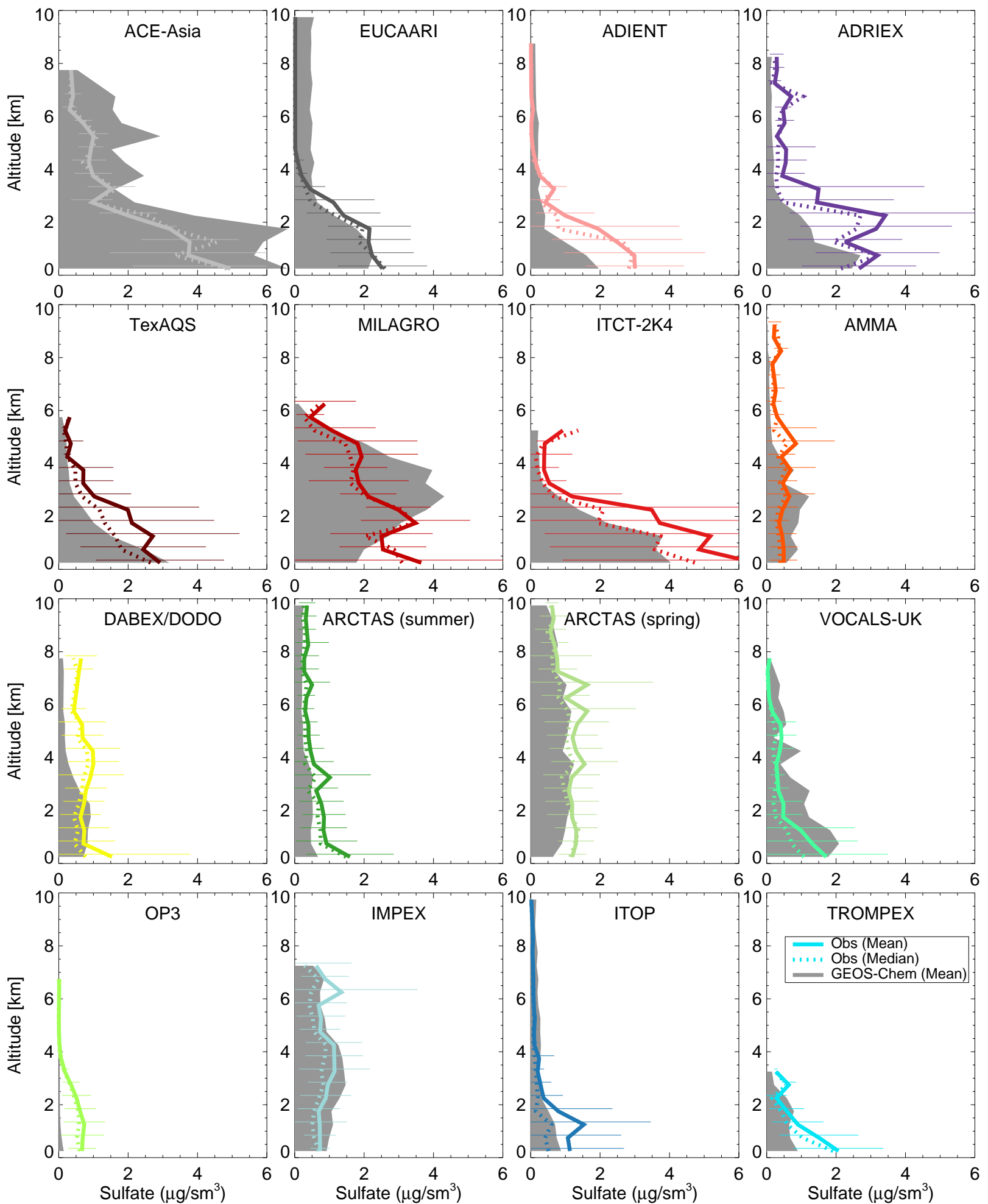

Fig. 4. Mean vertical profile of sulfate for 17 field campaigns (color, solid) with the mean GEOS-Chem simulation shown in grey. The standard deviation of the binned observations at each $0.5 \mathrm{~km}$ interval are also shown. Median observed values at each altitude are shown as dotted lines. The model simulation is sampled for the dates and locations of each aircraft campaign. 

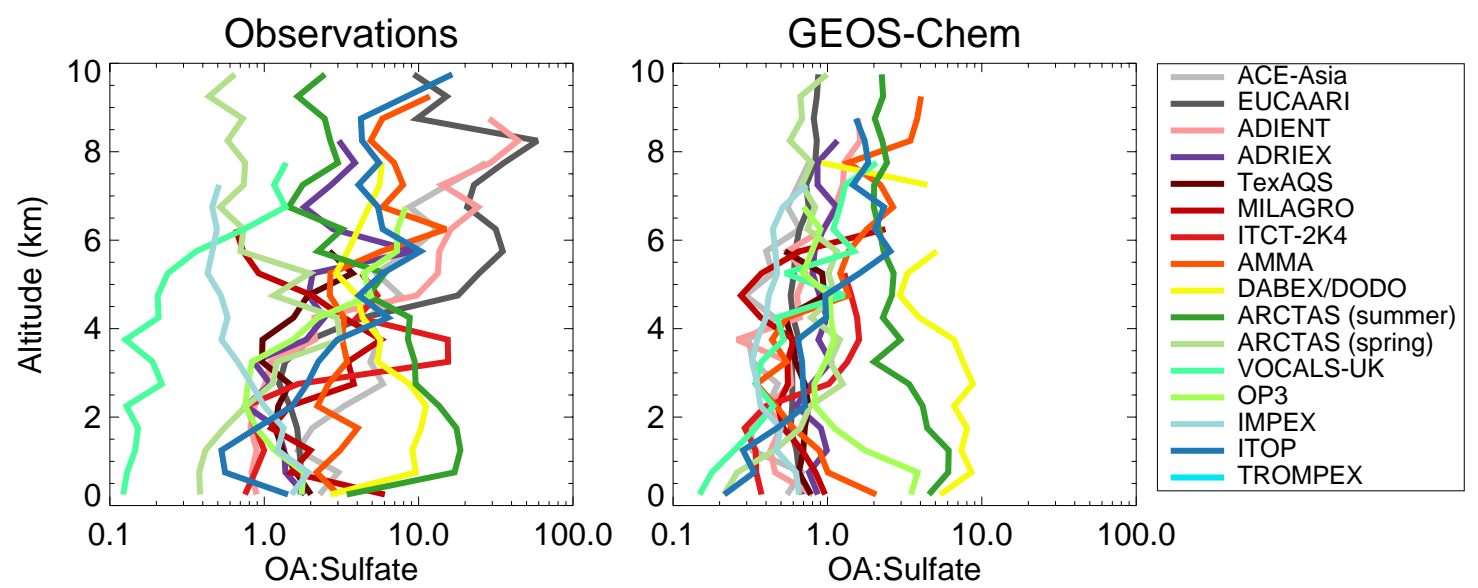

Fig. 5. The vertical profile of observed (left) and simulated (right) mean OA to mean sulfate ratio for 17 field campaigns. Altitudes where sulfate concentrations are reported as zero are not shown.
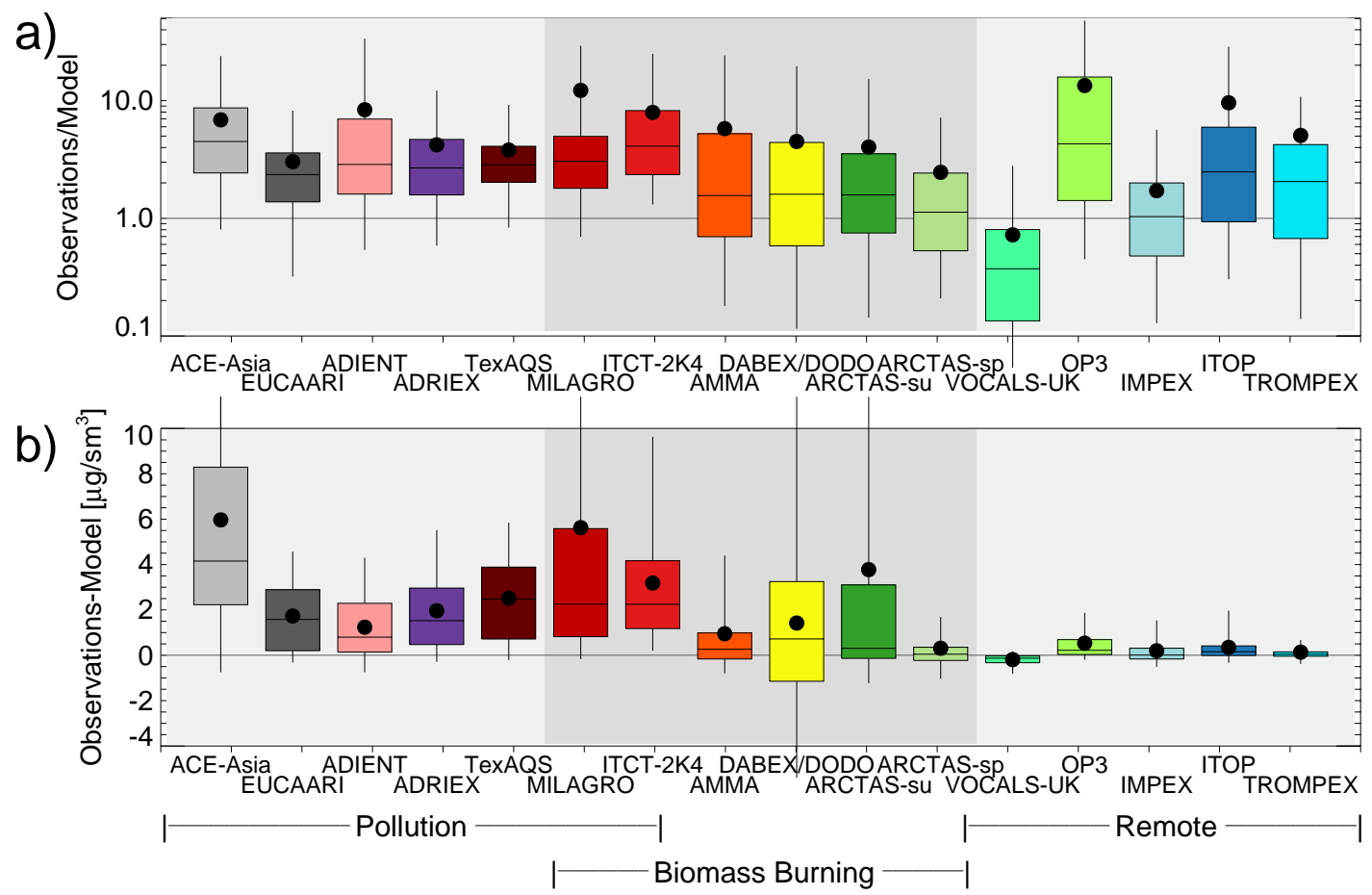

Fig. 6. Distribution of (a) ratio and (b) difference in observed and simulated (GEOS-Chem) OA concentrations for 17 field campaigns. Means of the gridded comparisons are shown as a solid dot, median as a horizontal line. The boxes denote 25 th and 75 th percentile, whiskers denote 5 th and 95 th percentile.

campaigns. This can be compared to Fig. 2 of Volkamer et al. (2006) (and Fig. 12 of Hodzic et al. (2010)) with some important differences. In particular, we compare here total OA measured to modeled, not SOA only as in Volkamer et al. (2006). Given that current analytical techniques cannot separate SOA from OA, this removes the uncertainty of whether the measured oxygenated OA may include aged primary emissions. Similarly, as definitions of SOA have evolved, modeled SOA in various studies may or may not include aged primary emissions. Composition analysis, though challenging, can help to untangle these contributions, but these constraints are not available here. Thus total OA is the more rigorous "apples to apples" comparison. Using the median as a metric to evaluate model performance (as in Sect. 4), we find that observations range from 0.4 to 4.2 of the simulated values, in the median. Median OA concentrations 

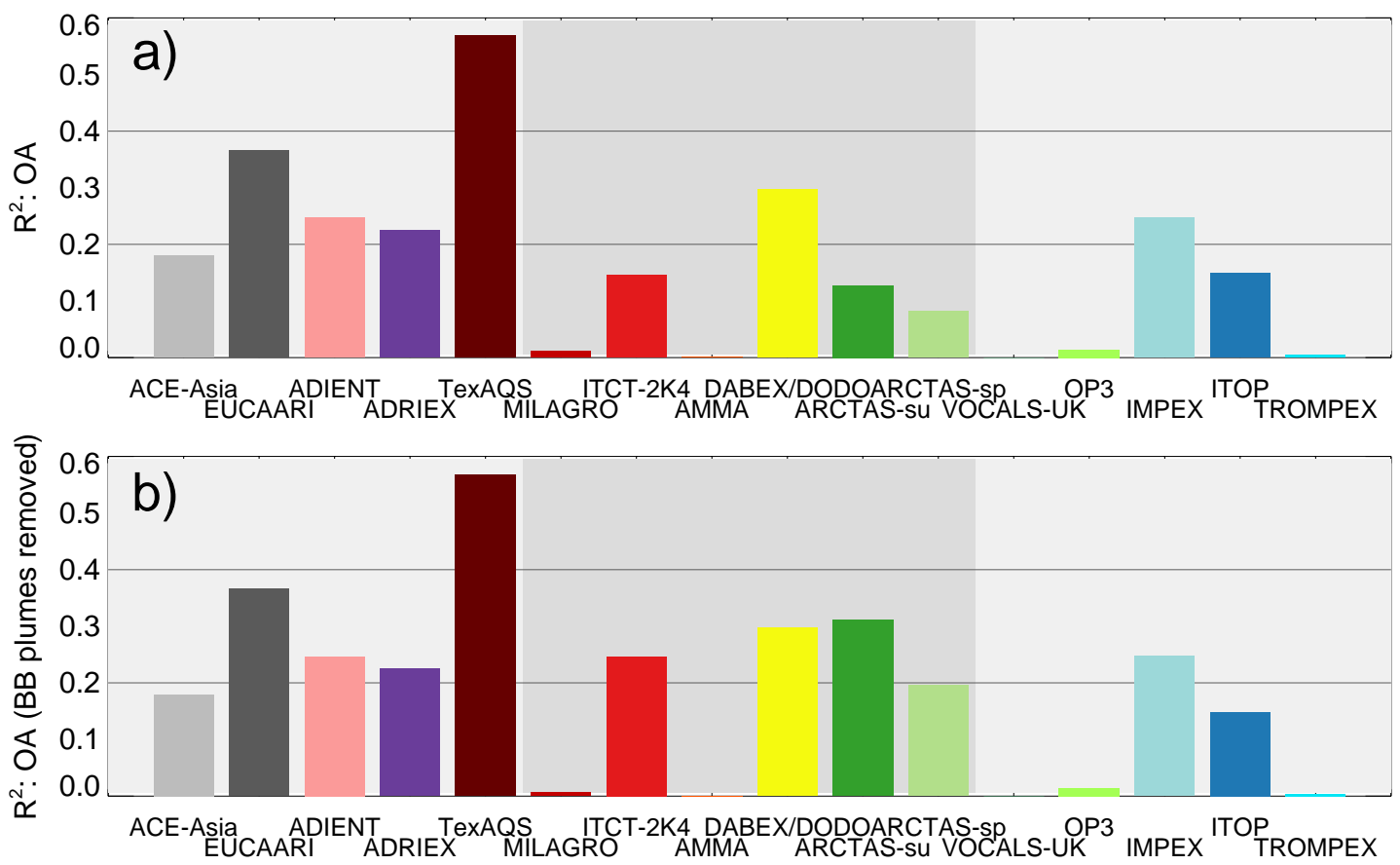

Fig. 7. Fraction of the observed variability reproduced by GEOS-Chem for each field campaign for (a) OA, (b) OA (with biomass burning plumes removed, see text).

are underestimated by the model in 13 of the 17 campaigns. The only significant model overestimate is for the VOCALSUK campaign, a remote campaign with low OA concentrations. Hawkins et al. (2010) report that ship-based AMS observations during this campaign were less than half of the FTIR measurements of OA made aboard the same platform, suggesting possible collection efficiency differences, particularly with marine organics. This may also influence lower tropospheric OA concentrations for the comparable airborne instrument. Model skill appears particularly poor for the OP3 campaign when examining the ratio of concentrations, but the differences show that these are ratios of small concentrations. The model simulates the median concentrations within $1 \mu \mathrm{g} \mathrm{sm}^{-3}$ for 11 of the 17 campaigns (ADIENT, the ARCTAS spring and summer campaigns, AMMA, DABEX \& DODO, VOCALS-UK, OP3, IMPEX, ITOP and TROMPEX). All of the 6 campaigns with a large model bias have been classified as being subject to significant anthropogenic influence. We find that the differences between modeled and observed OA concentrations are not limited to the free troposphere, but that rather the ratios and differences shown in Fig. 6 are consistent throughout the troposphere. A study by Wang et al. (2011) showed that mean concentrations of OA observed during the Spring ARCTAS campaign (including the enhancement due to fire emissions) are reproduced by GEOS-Chem when driven by the daily FLAMBE fire emission inventory. While the mean OA is underestimated here when using monthly-mean GFED emissions, the median is well captured. This again, emphasizes the importance of using the median as a metric in our comparisons, particularly in regions influenced by plumes. Our results differ from the picture established by Volkamer et al. (2006) that model bias increases with photochemical age. Instead here we find the model underestimate, both as a ratio and in absolute terms, is largest close to source. This may be indicative of a fragmentation loss of organics at long timescales (see Sect. 6.3). We note that here we access much longer aging timescales than Volkamer et al. (2006), with datasets that are far less influenced by continental sources. Indeed, we characterize ACE-Asia as a near-field campaign, unlike Volkamer et al. (2006) who consider this to be the most aged among the four campaigns they summarized.

As Fig. 6 suggests, there is a wide range of model performance for each aircraft campaign. One metric for this is the ability of the model to capture the variability in observed OA concentrations (Fig. 7). Model skill varies considerably; less than $10 \%$ of the variability is captured by the model for 5 campaigns, with a maximum of $57 \%$ of the variability in OA captured by GEOS-Chem for TexAQS. Note here that the observations have been averaged to the model spatial resolution, such that we do not penalize the model for its inability to capture sub-grid variability (see Sect. 2). This does not account for differences that can arise from aircraft sampling that inadequately captures the range of sub-grid variability (i.e. representation error). The poor model performance in some regions can be attributed to the inability 
of the model to capture fire plumes. When these concentrated plumes are filtered from our datasets (see Sect. 2), the variability in the remaining dataset is better represented for some campaigns (ITCT-2K4, ARCTAS spring and summer). A GEOS-Chem model simulation with a similar configuration as here but using daily varying fire emissions captures a greater fraction of the variability in the ARCTAS spring observations $\left(R^{2}=0.38\right.$ compared to 0.20$)$ Wang et al., 2011). Figure 7 indicates that model skill is highest in anthropogenically influenced regions. This may reflect the ability of the model to better capture the strong gradients from near source to background (driven by emission inventories and the processes of dilution and removal) versus the smaller range of variability in aged air masses. Variability in biomass burning influence may be the most difficult to reproduce, reflecting spatial and temporal changes in burn conditions and fuels that are not captured in emission inventories.

Recent studies have attempted to use more detailed information on the composition and volatility of observed OA to guide the evaluation of modeled OA (Spracklen et al., 2011; Jathar et al., 2011). One constraint used by both of these studies is the fraction of OA which is oxygenated (OOA) according to positive matrix factorization (PMF) analysis of AMS measurements. The OOA:OA ratios in surface observations from Zhang et al. (2007) exceed 0.6 in all cases, and are generally in the range of $0.85-1.0$, indicating a very small hydrocarbon-like aerosol contribution. In order to estimate this ratio in the model, we assume that only the hydrophobic POA $\left(\mathrm{POA}_{o}\right)$ is equivalent to the non-oxygenated hydrocarbon-like OA (HOA) reported for AMS measurements. Therefore our simulated OOA is the sum of hydrophilic or aged POA $\left(\mathrm{POA}_{i}\right)$ and SOA. Hydrophobic POA makes a very small contribution to global OA loading. Figure 8 shows the simulated OOA:OA ratios across the 17 aircraft campaigns, which range from 0.75 to 1.0 , consistent with reported AMS ratios in the literature (PMF analysis is not available for direct comparison for all the campaigns investigated here). Therefore, the correct range of OOA:OA is simulated even for campaigns with larger model bias or poor descriptions of observed variability. The OOA:OA ratio is therefore not necessarily a good discriminator of model skill, and can be simulated well for the wrong reasons. The degree of oxidation, represented for example by the oxygen to carbon ratio $(\mathrm{O}: \mathrm{C})$, may be a better test of model performance.

\section{Attributing Model-Measurement Discrepancy}

We investigate here whether the OA model bias discussed in Sects. 4 and 5 can be attributed to any particular source type or process.

\subsection{Aqueous phase SOA}

Both laboratory (Carlton et al., 2007) and field measurements (Sorooshian et al., 2007a, b, 2010; Hennigan et al., 2009) have provided evidence of aqueous phase formation of SOA, however the importance of this pathway to the global source of OA is unclear. Fu et al. (2008) estimated a global source of $11 \mathrm{Tg} \mathrm{yr}^{-1}$ of SOA formed through the irreversible uptake of dicarbonyls in clouds and aerosols, comparable to the source of SOA from the gas-phase pathway. Inclusion of this additional source of SOA in the GEOS-Chem model eliminated the low bias previously seen during ITCT-2K4, with a small improvement in the ability of the model to capture the observed variability in WSOC (Fu et al., 2009). Similarly, Carlton et al. (2008) find that including a detailed aqueous phase SOA mechanism in the CMAQ model modestly reduces (improves) the simulated bias (correlation) compared to the ITCT-2K4 measurements.

Figure 9 shows the vertical profile of the contribution of aqueous phase SOA simulated in the GEOS-Chem model based on the Fu et al. (2008) scheme. This figure is illustrative, as results from a 2006 simulation are sampled for the location and month of the field campaigns examined here, but neither year nor flight tracks are matched as in our previous comparisons. Fu et al. (2008) estimate that $\sim 90 \%$ of the simulated aqueous source is from in-cloud oxidation. The vertical profile of production in-aerosol and in-cloud (not shown) are very similar, and therefore are considered together here. Aqueous phase SOA makes up more than $20 \%$ of total OA at all altitudes, with a pronounced enhancement from $2-6 \mathrm{~km}$, where contributions vary from $40-80 \%$ of total simulated OA. This mid-tropospheric enhancement is not supported by the observed vertical profiles in Fig. 4, nor is the model-observation discrepancy (when aqueous SOA is not included) larger in this region of the troposphere. Thus, addition of the aqueous phase source, as currently described in the GEOS-Chem model, is unlikely to improve the model simulation, beyond a mean reduction in bias.

Previous studies have shown an enhancement of OA in the particle phase (Hennigan et al., 2009) or an enhancement of organic acids (Sorooshian et al., 2010) as a function of relative humidity (RH). Figure 10 shows that while sulfate concentrations (dominated by aqueous phase formation) increase with relative humidity, the OA relationship is not as clear, with only 6 of the 16 campaigns (no RH data for ACE-Asia available) demonstrating a non-negligible positive correlation. Note that values are only shown for RH bins which were well-sampled (i.e. $>2 \%$ of total measurements made at specific RH conditions). Figure 10 also shows that for 12 of the 16 campaigns the ratio of observed to simulated OA increases with relative humidity, with robust correlations $(R>0.60)$. This indicates that model bias may increase with humidity, possibly indicative of a missing role for aqueous phase SOA or enhanced OA partitioning in the presence of water (Pankow, 2010). Some of the campaigns where 


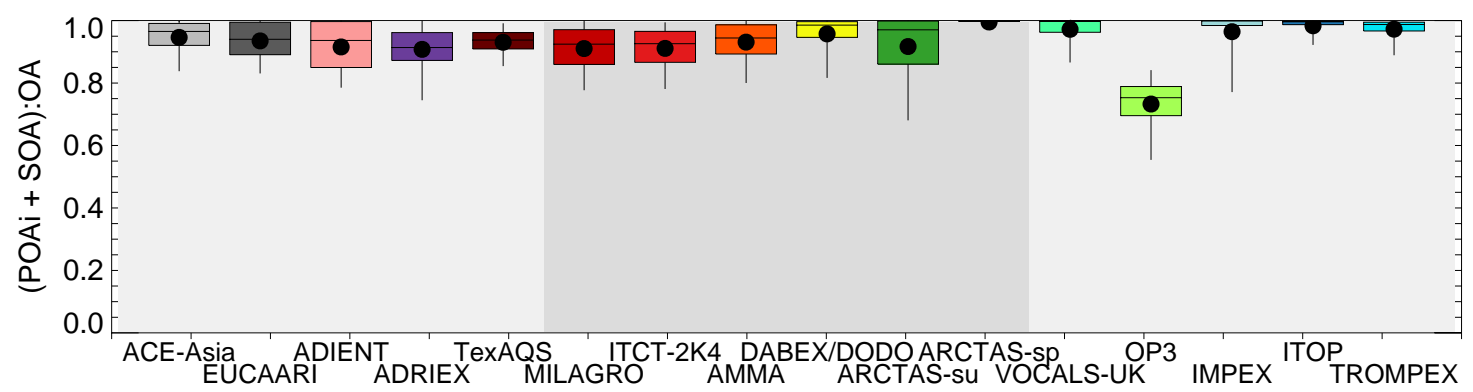

Fig. 8. OOA:OA simulated with GEOS-Chem for 17 aircraft field campaigns, where OOA is defined as the sum of SOA and hydrophilic POA. Means of the gridded model concentrations sampled along the aircraft profiles are shown as a solid dot, median as a horizontal line. The boxes denote 25 th and 75 th percentile, whiskers denote 5 th and 95 th percentile.

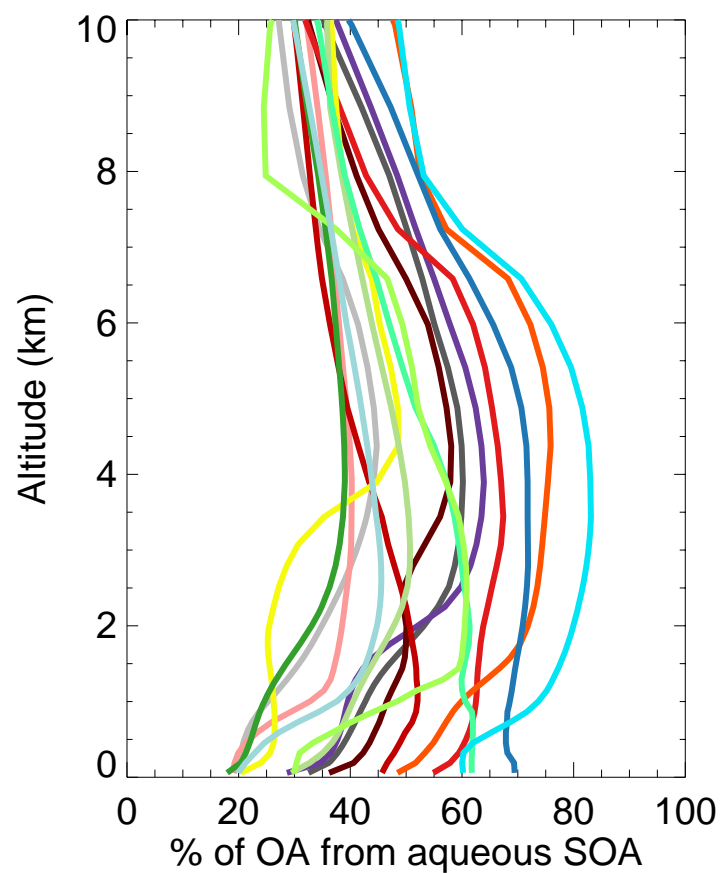

Fig. 9. Fraction of simulated OA produced from the aqueous-phase SOA mechanism of Fu et al. (2008). Monthly mean concentrations from a 2006 GEOS-Chem simulation have been sampled for the region/month of the 17 aircraft campaigns examined here (colors as in previous figures).

this relationship is not significantly correlated (ADRIEX and TROMPEX) sampled a very narrow range of relative humidity, and thus trends are difficult to establish. Given the variability in the observed concentrations, trends shown here are indicative rather than robust.

This analysis does not offer definitive evidence for the importance of aqueous phase SOA, but it does not preclude it. Additional chemical constraints are clearly required to investigate the importance of this source to the global OA budget.

\subsection{Increasing Existing OA Sources}

Spracklen et al. (2011) used AMS surface observations to optimize model OA sources in the GLOMAP model, estimating a $100 \mathrm{Tg} \mathrm{yr}^{-1}$ source of anthropogenically-controlled SOA, which also resulted in much better agreement with the IMPROVE observations over the US. SOA is formed irreversibly in the GLOMAP model. Our standard model simulation includes only 3.1 $\mathrm{Tg} \mathrm{yr}^{-1}$ of aromatic SOA (ASOA). Observed ambient OA composition from numerous field campaigns is more consistent with alkane than aromatic precursor species (Russell et al., 2011). Both sources share similar spatial emissions, and thus in absence of large differences in volatilities (associated with for example varying product distributions from the oxidation of alkanes of varying carbon chain length), we expect that the spatial distribution of SOA from either source would be similar. Given that the spatial (including vertical) distribution of ASOA and SOA from S/IVOCs as simulated by Pye and Seinfeld (2010) are also very similar to each other, we use modeled aromatic SOA as a proxy for any anthropogenically-controlled SOA. This assumption is highly general, given that different oxidation rates and volatilities could produce somewhat different vertical distributions. Biogenic SOA and primary (fresh and aged) sources here (Table 2) are only modestly higher than the estimates of Spracklen et al. (2011) (13 and $51 \mathrm{Tg} \mathrm{yr}^{-1}$ respectively). Figure 11 compares the observed airborne OA concentrations with the GEOS-Chem model when ASOA concentrations are increased 30-fold, to mimic an addition of $93 \mathrm{Tg} \mathrm{yr}^{-1}$ in the model (without allowing repartitioning in response to higher OA). The model simulation in anthropogenic regions improves dramatically when ASOA is increased, with almost perfect agreement of median values for ITCT-2K4, TexAQS, MILAGRO, ADIENT and ADRIEX. Observations from ACE-Asia, AMMA and OP3 remain underestimated. However, concentrations at both remote locations (IMPEX, ITOP, TROPEX, VOCALSUK) and aloft in some locations (ARCTAS, EUCAARI) are overestimated with this additional source. This may suggest 

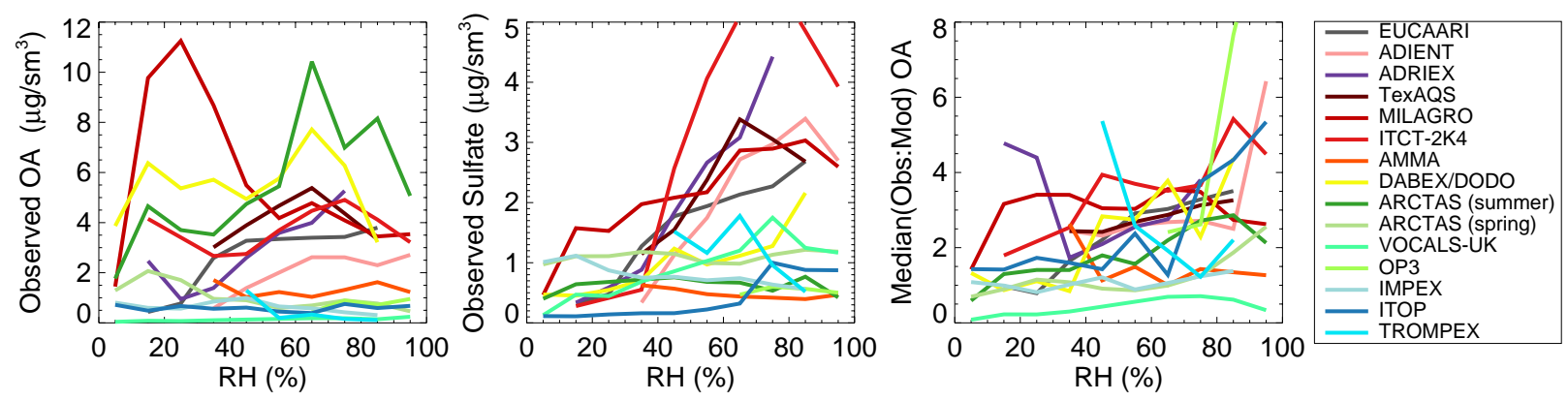

Fig. 10. Mean observed organic aerosol (left), sulfate (middle) concentrations as a function of relative humidity for 16 aircraft field campaigns. Final panel (right) shows median observed to simulated ratio of OA concentrations as a function of measured relative humidity for each campaign. Data is averaged in $10 \% \mathrm{RH}$ bins. Data is only shown when the number of points per bin exceeds $2 \%$ of the total observations (to eliminate undersampling).

that either the lifetime of ASOA is shorter than simulated, or that the volatility is higher (see Sect. 6.3). The vertical profile simulated by the model reflects a particular mix of non-volatile and semi-volatile organics, with volatility and yields estimated from chamber experiments. For example, aromatic SOA has higher yields at low $\mathrm{NO}_{\mathrm{x}}$, but it is also non-volatile in the model, and is therefore relatively enhanced at higher altitudes, where dilution would partition semi-volatile SOA to the gas phase. Thus, the overestimate aloft apparent in Fig. 11 could also suggest that aromatic SOA at low $\mathrm{NO}_{\mathrm{x}}$ should be semi-volatile, or that the porportion of SOA formed under low $\mathrm{NO}_{\mathrm{x}}$ conditions is overestimated in the model. This would also be consistent with a greater S/IVOC source rather than an aromatic SOA source. We conclude here only that the observations are consistent with higher volatility OA but do not attempt to use the vertical profile to constrain the contribution of SOA at different volatilities. Overall, the increase in ASOA suggested by Spracklen et al. (2011) is consistent with observations close to source (well represented in the surface dataset used by those authors), but may not be consistent with the remote campaigns and locations included here.

We note that while scaling the ASOA concentrations is an efficient means of testing this hypothesis (i.e. does not require new model simulations), it neglects the non-linearity of SOA partitioning. We performed a sensitivity simulation for 2008 where aromatic precursor emissions were increased directly. When the results of this are compared to scaling our standard simulation (with total burdens normalized) we see that non-linear partitioning shifts the OA mass to the high ASOA concentration regions as expected. As a result, concentrations in the Northern Hemisphere are higher than when this effect is not taken into account, by up to $15 \%$ at the surface near sources, and uniformly by $\sim 5 \%$ in the free troposphere. Thus, simulated concentrations shown in Fig. 11 are slightly lower than would be expected if non-linear partitioning were accounted for.
Scaling biogenic SOA (BSOA) concentrations to add 4fold the concentrations (approximately equivalent to adding $94 \mathrm{Tg} \mathrm{yr}^{-1}$, again, neglecting non-linear partitioning effects), produces surprisingly similar results to when ASOA is increased (Fig. S4). Our anthropogenic environments all include significant fractions of BSOA, and increasing the BSOA eliminates model-observation discrepancies for ITCT2K4, TexAQS, MILAGRO, and ADRIEX. Concentrations remain underestimated for ACE-Asia, AMMA and OP3, but are also low in this case for ADIENT and EUCAARI (in the boundary layer). Simulated remote concentrations remain high.

Figure 12 attempts to differentiate the model performance with these additional sources. The relative change in the ability of the model to reproduce the observed variability is shown for each campaign when simulated ASOA is increased by 30 , when BSOA is increased by 4 and when POA is tripled (all equilvalent to an addition of $\sim 100 \mathrm{Tg} \mathrm{yr}^{-1}$ ). We see modest improvements in model skill $(<7 \%)$ for 5 campaigns (all anthropogenically-influenced) when ASOA is increased, with slightly diminished performance for 4 campaigns. Increasing BSOA in the model results in lesser improvements, and almost no model skill improvement is evident when simulated POA is tripled. This result is consistent with Spracklen et al. (2011) who found that increasing either anthropogenic or biogenic SOA sources reduced the GLOMAP model bias, but that only increasing anthropogenic sources enhanced the correlation with observations. However, this result should not be over-interpreted, as the change in $R^{2}$ here is modest, suggesting (as expected) that the model is missing key sources of variability. The GEOSChem simulation employed here does not include $\mathrm{NO}_{\mathrm{x}}$ dependent yields for monoterpenes and sesquiterpenes. $\mathrm{Ng}$ et al. (2007a) show that monoterpene yields are enhanced at low $\mathrm{NO}_{\mathrm{x}}$, while sesquiterpene yields are reduced. The model may therefore be neglecting an interaction between anthropogenic sources and BSOA, blurring the lines of source attribution and resulting in more modest improvements in the 

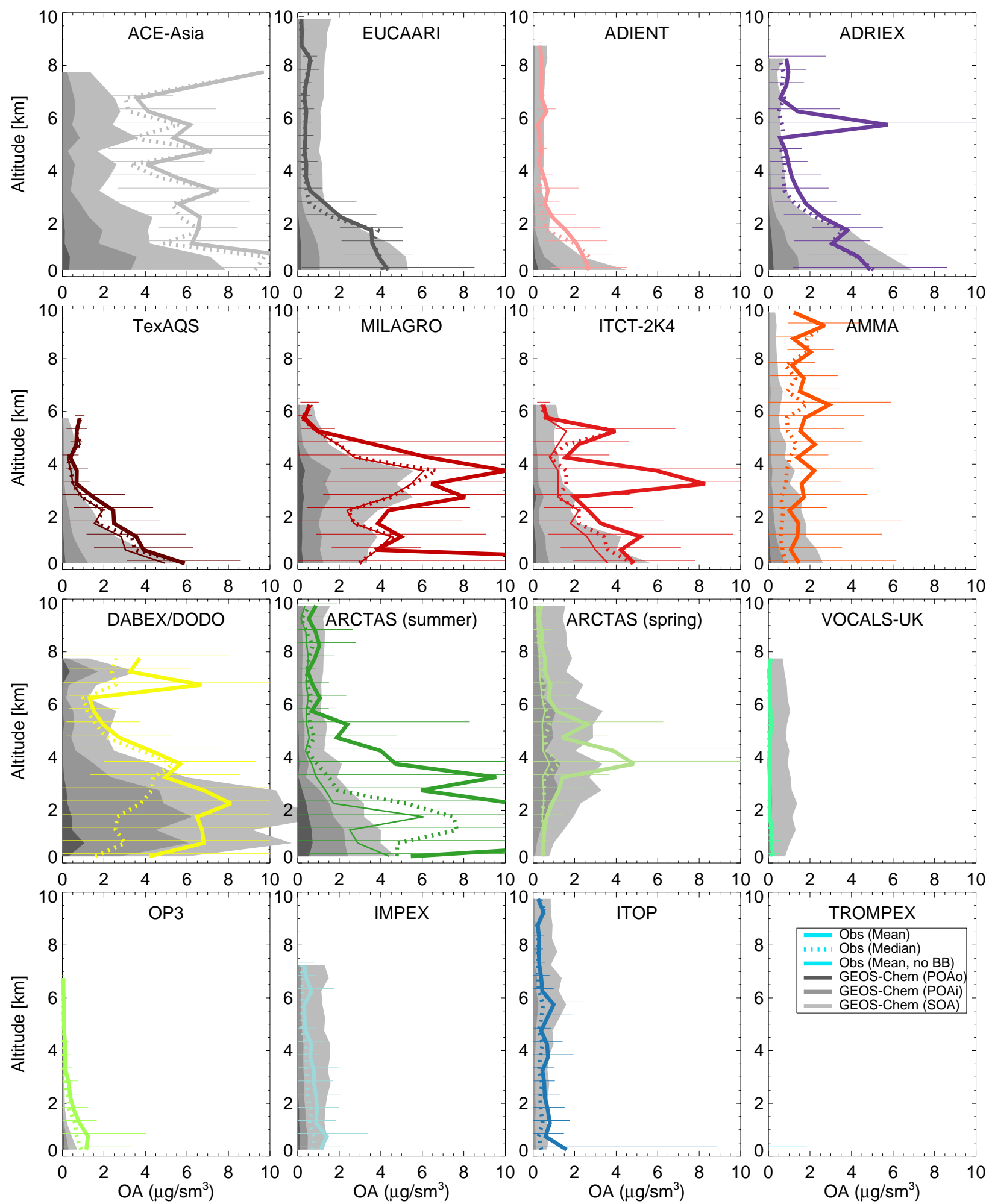

Fig. 11. As in Fig. 4, mean simulated OA (grey) is compared to observed (color) concentrations for 17 field campaigns, however the model simulation here includes an additional source of anthropogenic SOA (ASOA) of $100 \mathrm{Tg} \mathrm{yr}^{-} 1$ estimated by scaling simulated ASOA by a factor of 30 . 


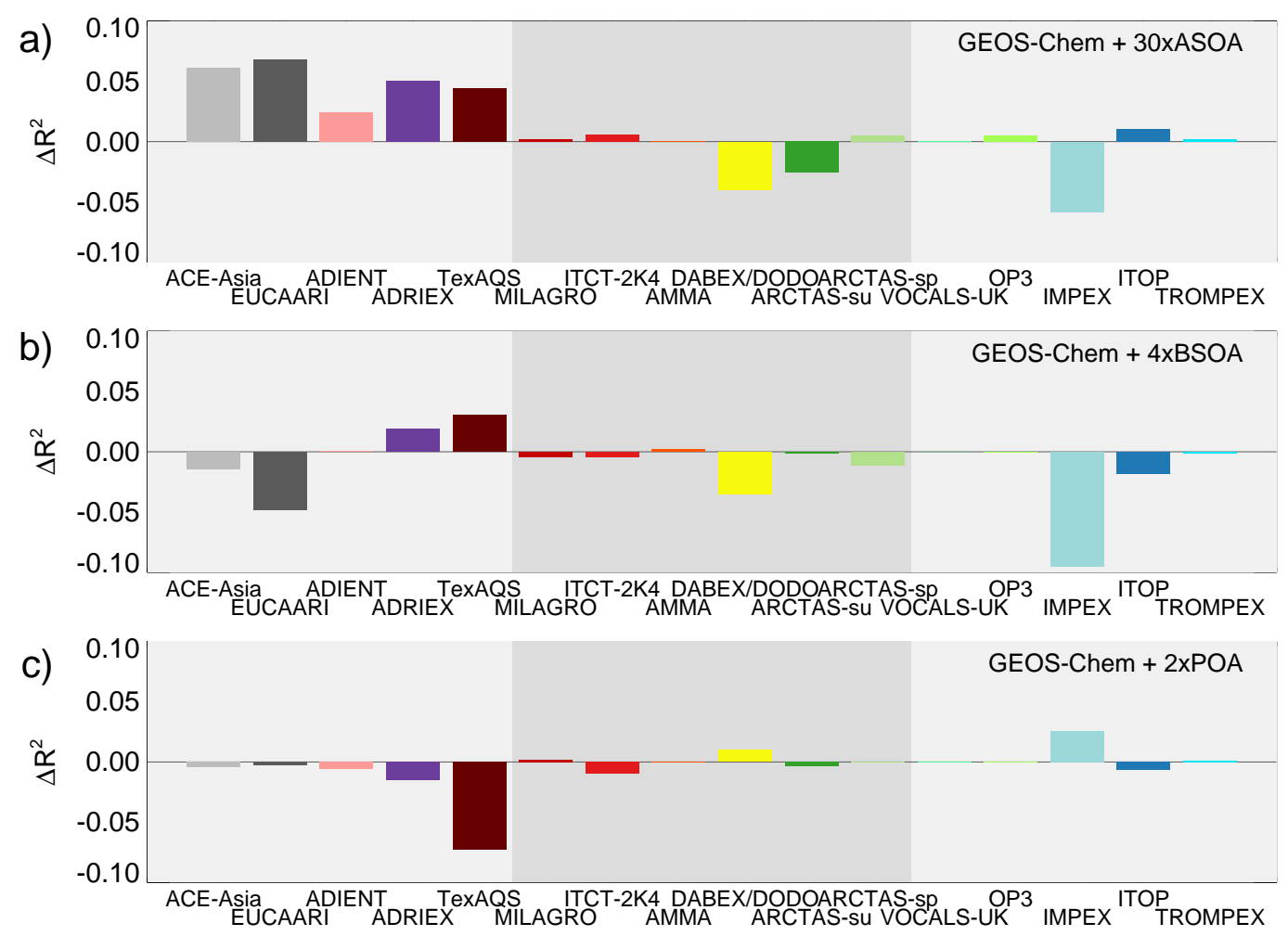

Fig. 12. The change in $R^{2}$ between simulated (GEOS-Chem) and observed OA for each campaign for various sensitivity simulations (labeled in inset). Each addition represents an additional source of $100 \mathrm{Tgyr}^{-1}$ of OA. Compare to baseline in Fig. $7 \mathrm{a}$.
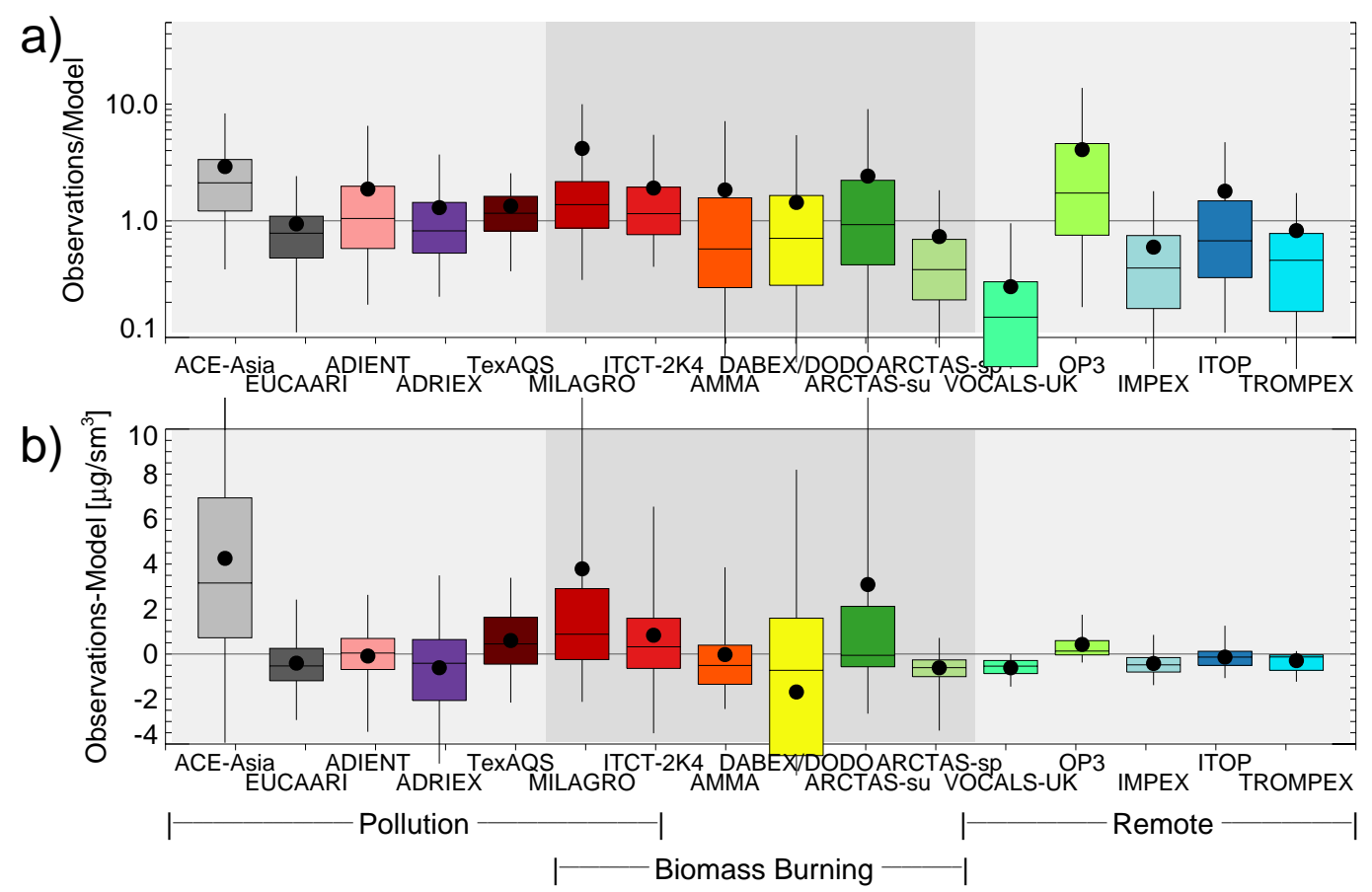

Fig. 13. As in Fig. 6, but with the 30-fold of increase in ASOA in the model and the reduction of the enthalpy of vaporization of SOA to $25 \mathrm{kJmol}^{-1}$. 
simulation when BSOA sources (as currently treated) are increased in the model. Furthermore, a lack of improvement in correlation when increasing existing sources in the model could reflect spatial mis-representation of emission inventories.

One additional avenue to increase OA loading in the model is via a decrease in removal. A sensivity simulation performed for 2008 indicates that decreasing the SOA wet removal efficiency by a factor of 2 increases the global burden (and local concentrations) by less than $10 \%$. This does not address a possible bias in the assimilated meteorology rain frequency and amount, however as discussed in Sect. 3, previous model evaluations of aerosol wet deposition are largely unbiased. Therefore it is highly unlikely that excessive removal of $\mathrm{OA}$ in the model could make more than a minor contribution to the model bias.

\subsection{Increasing the loss of $\mathrm{OA}$}

The comparison of Fig. 11 suggests that additional sinks of OA may be required in the model to reproduce the low concentrations in remote regions. Parameterized wet removal in models is highly uncertain and could perhaps account for such an additional loss. However, as discussed in Sect. 3, the unbiased simulation of wet removal of inorganics, and the high solubilities assumed for the gas and particle phase organics in the GEOS-Chem model, suggest that if anything wet deposition may be overestimated in our simulation. This highlights the need for observational constraints on OA deposition. Until that time, we can only conjecture that this is not the cause of our model bias.

In order to reduce OA loading aloft we conduct an additional sensitivity simulation where the enthalpy of vaporization of SOA is reduced to $25 \mathrm{kJmol}^{-1}$, estimated based on Cappa and Jimenez (2010), in order to dampen the simulated volatility decrease at low temperatures. We note that this enthalpy of vaporization is shown by Cappa and Jimenez (2010) to be the best parameterized fit for the lumped 2-product model of SOA, and does not represent a physically realistic enthalpy of vaporization for any given organic compound, as discussed by Donahue et al. (2006) and Cappa and Jimenez (2010). This decrease in enthalpy of vaporization effectively increases the volatility of SOA away from sources. This reduces the global mean burden of SOA by $\sim 50 \%$. We find that this decrease in the enthalpy of vaporization largely corrects the overestimates in OA observed in remote conditions and aloft, with boundary layer concentrations essentially unchanged. Figure 13 repeats the evaluation of Fig. 6 with the 30-fold increase in ASOA and the decrease in enthalpy of vaporization. With these updates, median simulated OA concentrations are within $1 \mu \mathrm{g} \mathrm{sm}^{-3}$ for 15 of 17 campaigns. ACE-Asia concentrations remain underestimated, whereas the DABEX/DODO campaign, which is almost exclusively influenced by biomass burning, is overes- timated when ASOA is increased. However, while a relative increase in volatility away from source could help reconcile our model simulation with observations, this seems physically unlikely given that aged organic aerosol is expected to decrease in volatility (Jimenez et al., 2009).

Alternate sensitivity simulations were performed to include a loss process from fragmentation. Previous work has shown that heterogeneous oxidation can lead to the breaking of carbon-carbon bonds, producing smaller fragment organics, with higher volatility (Molina et al., 2004; Kroll et al., 2009). This has been postulated both as a source of gasphase organics (Kwan et al., 2006) and as a possible sink for OA over long timescales (weeks) (Kroll et al., 2011; Smith et al., 2009). However this loss process critically depends on the branching ratio between fragmentation and functionalization, which is poorly constrained. We include this in our sensitivity simulation by oxidizing SOA with $\mathrm{OH}$ $\left(\mathrm{k}_{\mathrm{OH}}=1 \times 10^{-12} \mathrm{~cm}^{3}\right.$ molecule $\left.{ }^{-1} \mathrm{~s}^{-1}\right)$ and assuming that $5 \%$ of the products are lost via fragmentation (the remainder is retained as SOA). We have little experimental guidance on the appropriate branching ratio, and thus $5 \%$ is assumed as a seemingly modest but reasonable value. Such a loss reduces the global annual mean SOA burden by $15 \%$, with largest relative decreases aloft ( $<25 \%$ mean change in concentration). This is consistent with the estimate that up to $20 \%$ of $\mathrm{OA}$ can be lost at high (long) $\mathrm{OH}$ exposures based on ambient aging experiments (George et al., 2008). The addition of this sink of SOA brings the model into slightly better agreement with observations (when ASOA levels remain at 30-fold levels), but the simulation remains biased high in remote regions and aloft.

Fragmentation from gas-phase oxidation of semi-volatile organics can prevent the formation of SOA (Kroll et al., 2007; Chan et al., 2007). An alternate set of simulations were performed to assess the potential importance of this process on the SOA budget. The gasphase fraction of semi-volatile organics (SOG) are oxidized by $\mathrm{OH} 20$ times faster than the heterogeneous path $\left(\mathrm{k}_{\mathrm{OH}}=2 \times 10^{-11} \mathrm{~cm}^{3}\right.$ molecule ${ }^{-1} \mathrm{~s}^{-1}$, matching the value employed by Grieshop et al. (2009)) with the same assumption that $5 \%$ of the oxidized mass is lost via fragmentation per each reaction. This fast oxidation reduces the SOA burden globally by $47 \%$. In terms of comparisons with observations the results are remarkably similar to the results obtained when the enthalpy of vaporization is decreased. SOA concentrations are reduced aloft and remotely by $40-60 \%$, bringing the model into better agreement with the observations (assuming a concurrent 30 -fold increase in ASOA). However, it is likely that this implementation is an upperlimit on the loss of gas-phase organics, given that aged organics are likely of lower volatility, and thus less likely to be found (and lost) in the gas-phase.

While the model bias can be successfully eliminated by a combination of increasing sources and the sinks discussed here, none of the sensitivity experiments undertaken to 
reduce the OA bias aloft/remotely substantially improve the model's ability to capture the observed variability.

\section{Discussion and conclusions}

The datasets used here represent the most spatially diverse set of observations of organic aerosol and include a critical vertical dimension to the sampling. The observations of elevated OA in the free troposphere from ACE-Asia (Maria et al., 2004; Huebert et al., 2004; Mader et al., 2002) remain an outlier, and contrary to Heald et al. (2005), the other datasets examined here do not support a sustained source of organic aerosol in the free troposphere. Rather they indicate that atmospheric organic aerosol is primarily of surface origin, with significant enhancements aloft from injected fire plumes.

One key environment is not adequately represented in this dataset: the clean forested region (both tropical and boreal) at the peak of the biogenic emissions season. The OP3 campaign may best fall in this category, however much of the sampling was performed over the Celebes and Sulu Seas, and not necessarily in biogenic outflow. The summer ARCTAS and EUCAARI campaigns preferentially characterize the boreal regions, however there are considerable boreal fire and Northern European anthropogenic influences in these campaigns, respectively. Nevertheless, the observed concentrations from these campaigns suggest that OA loading close to biogenic sources is modest in comparison to more anthropogenically-influenced regions. High biogenic SOA events such as those reported by Slowik et al. (2010) are thus not characterized in this dataset.

These observations are employed to perform the most extensive evaluation of a model simulation of organic aerosol concentrations to date. GEOS-Chem simulations are performed for the specific meteorology and emissions of each given campaign from 2001 to 2009 and matched to the aircraft flight tracks. We find that the standard GEOS-Chem simulation underpredicts median observed OA in 13 of the 17 field campaigns (median observed to simulated ratios ranging from 0.4-4.2).

Analysis of these observations and the modelmeasurement discrepancies does not provide definitive evidence of (missing) aqueous phase sources of SOA in the model. However the increasing model bias as a function of relative humidity is an indicator that this process requires further study. Estimating the importance of this production pathway to the global budget will require additional chemical constraints, for example via tracers such as oxalate.

The comparison of these airborne observations with the GEOS-Chem simulation highlights the uncertainty associated with organic aerosol lifetime and loss. We demonstrate here that remote concentrations of OA are highly sensitive to increasing losses, via for example, the decrease in temperature sensitivity of OA partitioning (via the enthalpy of vaporization) and the addition of an oxidation loss of organics.
These processes, in addition to depositional loss, ultimately control concentrations down-wind of sources. The relative roles of changing volatility, chemical loss and physical removal are poorly constrained and require further investigation. However we find that concentrations in remote regions are generally low $\left(<1 \mu \mathrm{g} \mathrm{sm}^{-3}\right)$ and thus are unlikely to contribute substantially to air quality degradation.

Conversely, we find that in proximity to source regions, GEOS-Chem is able to reproduce much of the observed variability and vertical gradient in concentrations. While the model underestimate is largest here (but less than a factor of 5 in the median), the bias is largely eliminated in these regions when anthropogenic SOA sources are increased to $\sim 100 \mathrm{Tg} \mathrm{yr}^{-1}$. We do not further distinguish the nature of this source (e.g. S/IVOCs, higher aromatic SOA, alkane-derived SOA, or anthropogenically controlled biogenic SOA), howevern idealized series of simulations which characterize the spatial patterns of OA simulated as a function of emission source, reaction rate and volatility could be used to investigate this further. However, our conclusions are consistent with Spracklen et al. (2011) who employed a different global model, with a different SOA scheme, to investigate a different set of observations, lending some confidence to the robustness of these results. As the body of observational constraints grows it will be useful to compare concentrations simulated by models with different chemical schemes and driven by different meteorology. Furthermore, higher spatial resolution simulations may both reduce model biases and provide better opportunities to investigate processing timescales, particularly close to source.

As theoretical and laboratory investigations provide new potential mechanisms for OA formation and processing for models, it is essential that the ability of these models to then reproduce diverse field observations remains the primary arbiter of performance. This dataset represents over a decade of field sampling by numerous groups and is a global benchmark for OA modeling. Future aircraft measurements in the Southern Hemisphere, in Asia, over the clean tropical and boreal forested regions, and in multiple seasons would be extremely useful to round out this characterization of global OA distributions.

\section{Supplementary material related to this article is available online at: http://www.atmos-chem-phys.net/11/12673/2011/ acp-11-12673-2011-supplement.pdf.}

Acknowledgements. This work was supported by NSF-092928. We'd like to thank Joost de Gouw, Thomas Karl, Jennifer Murphy Carsten Warneke and Armin Wisthaler for use of their aceontrile measurements. We thank NERC for providing support for the BAe-146 experiments (grants: NE/D013690/1; NE/F019874/1; NE/B505562/1; NE/E01108X/1; NE/C517292/1; NER/T/S/2002/00579; NE/D004624/1 NE/E011101/1). We thank the European Union for providing support for the Bae-146 
EUCAARI project 036833-2. The University of Colorado group was supported by NASA NNX08AD39G, DOE DE-FG0211ER65293, NOAA NA08OAR4310565, and NSF ATM-0919189. ACE-Asia measurements were supported by NSF grants ATM0002035 and ATM-0002698 and by NASA grant NAG5-8676. UK airborne data was obtained using the BAe-146-301 Atmospheric Research Aircraft [ARA] flown by Directflight Ltd and managed by the Facility for Airborne Atmospheric Measurements [FAAM], which is a joint entity of the Natural Environment Research Council [NERC], the Met Office, and National Centre for Atmospheric Science [NCAS].

Edited by: J. H. Seinfeld

\section{References}

Aiken, A. C., Decarlo, P. F., Kroll, J. H., Worsnop, D. R., Huffman, J. A., Docherty, K. S., Ulbrich, I. M., Mohr, C., Kimmel, J. R., Sueper, D., Sun, Y., Zhang, Q., Trimborn, A., Northway, M., Ziemann, P. J., Canagaratna, M. R., Onasch, T. B., Alfarra, M. R., Prevot, A. S. H., Dommen, J., Duplissy, J., Metzger, A., Baltensperger, U., and Jimenez, J. L.: O/C and OM/OC ratios of primary, secondary, and ambient organic aerosols with highresolution time-of-flight aerosol mass spectrometry, Environ. Sci. Technol., 42, 4478-4485, doi:10.1021/es703009q, 2008.

Alexander, B., Park, R. J., Jacob, D. J., Li, Q. B., Yantosca, R. M., Savarino, J., Lee, C. C. W., and Thiemens, M. H.: Sulfate formation in sea-salt aerosols: Constraints from oxygen isotopes, J. Geophys. Res.-Atmos., 110, D10307, doi:10.1029/2004JD005659, 2005.

Allen, G., Coe, H., Clarke, A., Bretherton, C., Wood, R., Abel, S. J., Barrett, P., Brown, P., George, R., Freitag, S., McNaughton, C., Howell, S., Shank, L., Kapustin, V., Brekhovskikh, V., Kleinman, L., Lee, Y.-N., Springston, S., Toniazzo, T., Krejci, R., Fochesatto, J., Shaw, G., Krecl, P., Brooks, B., McMeeking, G., Bower, K. N., Williams, P. I., Crosier, J., Crawford, I., Connolly, P., Allan, J. D., Covert, D., Bandy, A. R., Russell, L. M., Trembath, J., Bart, M., McQuaid, J. B., Wang, J., and Chand, D.: South East Pacific atmospheric composition and variability sampled along $20 \mathrm{~S}$ during VOCALS-REx, Atmos. Chem. Phys., 11, 5237-5262, doi:10.5194/acp-11-5237-2011, 2011.

Bahreini, R., Ervens, B., Middlebrook, A. M., Warneke, C., de Gouw, J. A., DeCarlo, P. F., Jimenez, J. L., Brock, C. A., Neuman, J. A., Ryerson, T. B., Stark, H., Atlas, E., Brioude, J., Fried, A., Holloway, J. S., Peischl, J., Richter, D., Walega, J., Weibring, P., Wollny, A. G., and Fehsenfeld, F. C.: Organic aerosol formation in urban and industrial plumes near Houston and Dallas, Texas, J. Geophys. Res.-Atmos., 114, D00f16 doi:10.1029/2008jd011493, 2009.

Bond, T. C., Bhardwaj, E., Dong, R., Jogani, R., Jung, S. K., Roden, C., Streets, D. G., and Trautmann, N. M.: Historical emissions of black and organic carbon aerosol from energy-related combustion, 1850-2000, Glob. Biogeochem. Cy., 21, 16, Gb2018 doi:10.1029/2006gb002840, 2007.

Brock, C. A., Hudson, P. K., Lovejoy, E. R., Sullivan, A., Nowak, J. B., Huey, L. G., Cooper, O. R., Cziczo, D. J., de Gouw, J., Fehsenfeld, F. C., Holloway, J. S., Hubler, G., Lafleur, B. G., Murphy, D. M., Neuman, J. A., Nicks, D. K., Orsini, D. A., Parrish, D. D., Ryerson, T. B., Tanner, D. J., Warneke, C., We- ber, R. J., and Wilson, J. C.: Particle characteristics following cloud-modified transport from Asia to North America, J. Geophys. Res.-Atmos., 109, doi:10.1029/2003JD004198, 2004.

Canagaratna, M. R., Jayne, J. T., Jimenez, J. L., Allan, J. D., Alfarra, M. R., Zhang, Q., Onasch, T. B., Drewnick, F., Coe, H., Middlebrook, A., Delia, A., Williams, L. R., Trimborn, A. M., Northway, M. J., DeCarlo, P. F., Kolb, C. E., Davidovits, P., and Worsnop, D. R.: Chemical and microphysical characterization of ambient aerosols with the aerodyne aerosol mass spectrometer, Mass Spectrom. Rev., 26, 185-222, 2007.

Capes, G., Johnson, B., McFiggans, G., Williams, P. I., Haywood, J., and Coe, H.: Aging of biomass burning aerosols over West Africa: Aircraft measurements of chemical composition, microphysical properties, and emission ratios, J. Geophys. Res.Atmos., 113, D00C15, doi:10.1029/2008JD009845, 2008.

Capes, G., Murphy, J. G., Reeves, C. E., McQuaid, J. B., Hamilton, J. F., Hopkins, J. R., Crosier, J., Williams, P. I., and Coe, H.: Secondary organic aerosol from biogenic VOCs over West Africa during AMMA, Atmos. Chem. Phys., 9, 3841-3850, doi:10.5194/acp-9-3841-2009, 2009.

Cappa, C. D. and Jimenez, J. L.: Quantitative estimates of the volatility of ambient organic aerosol, Atmos. Chem. Phys., 10, 5409-5424, doi:10.5194/acp-10-5409-2010, 2010.

Carlton, A. G., Turpin, B. J., Lim, H. J., Altieri, K. E., and Seitzinger, S.: Link between isoprene and secondary organic aerosol (SOA): Pyruvic acid oxidation yields low volatility organic acids in clouds, Geophys. Res. Lett., 33, L06822, doi:10.1029/2005GL025374, 2006.

Carlton, A. G., Turpin, B. J., Altieri, K. E., Seitzinger, S., Reff, A., Lim, H. J., and Ervens, B.: Atmospheric oxalic acid and SOA production from glyoxal: Results of aqueous photooxidation experiments, Atmos. Environ., 41, 7588-7602, 2007.

Carlton, A. G., Turpin, B. J., Altieri, K. E., Seitzinger, S. P., Mathur, R., Roselle, S. J., and Weber, R. J.: CMAQ Model Performance Enhanced When In-Cloud Secondary Organic Aerosol is Included: Comparisons of Organic Carbon Predictions with Measurements, Environ. Sci. Technol., 42, 87988802, 10.1021/es801192n, 2008.

Chan, A. W. H., Kroll, J. H., Ng, N. L., and Seinfeld, J. H.: Kinetic modeling of secondary organic aerosol formation: effects of particle- and gas-phase reactions of semivolatile products, Atmos. Chem. Phys., 7, 4135-4147, doi:10.5194/acp-7-4135-2007, 2007.

Chen, Q., Farmer, D. K., Schneider, J., Zorn, S. R., Heald, C. L., Karl, T. G., Guenther, A., Allan, J. D., Robinson, N., Coe, H., Kimmel, J. R., Pauliquevis, T., Borrmann, S., Pöschl, U., Andreae, M. O., Artaxo, P., Jimenez, J. L., and Martin, S. T.: Mass spectral characterization of submicron biogenic organic particles in the Amazon Basin, Geophys. Res. Lett., 36, doi:10.1029/2009GL039880, 2009.

Chung, S. H. and Seinfeld, J. H.: Global distribution and climate forcing of carbonaceous aerosols, J. Geophys. Res.-Atmos., 107, doi:10.1029/2001JD001397, 4407, 2002.

Crosier, J., Allan, J. D., Coe, H., Bower, K. N., Formenti, P., and Williams, P. I.: Chemical composition of summertime aerosol in the Po Valley (Italy), northern Adriatic and Black Sea, Q. J. Roy. Meteorol. Soc., 133, 61-75, doi:10.1002/qj.88, 2007.

Cubison, M. J., Ortega, A. M., Hayes, P. L., Farmer, D. K., Day, D., Lechner, M. J., Brune, W. H., Apel, E., Diskin, G. S., Fisher, 
J. A., Fuelberg, H. E., Hecobian, A., Knapp, D. J., Mikoviny, T., Riemer, D., Sachse, G. W., Sessions, W., Weber, R. J., Weinheimer, A. J., Wisthaler, A., and Jimenez, J. L.: Effects of aging on organic aerosol from open biomass burning smoke in aircraft and laboratory studies, Atmos. Chem. Phys., 11, 12049-12064, doi:10.5194/acp-11-12049-2011, 2011.

de Gouw, J. and Jimenez, J. L.: Organic Aerosols in the Earth's Atmosphere, Environ. Sci. Technol., 43, 7614-7618, doi:10.1021/es9006004, 2009.

de Gouw, J. A., Middlebrook, A. M., Warneke, C., Goldan, P. D., Kuster, W. C., Roberts, J. M., Fehsenfeld, F. C., Worsnop, D. R., Canagaratna, M. R., Pszenny, A. A. P., Keene, W. C., Marchewka, M., Bertman, S. B., and Bates, T. S.: Budget of organic carbon in a polluted atmosphere: Results from the New England Air Quality Study in 2002, J. Geophys. Res.-Atmos., 110, D16305, doi:10.1029/2004JD005623, 2005.

de Gouw, J. A., Warneke, C., Stohl, A., Wollny, A. G., Brock, C. A., Cooper, O. R., Holloway, J. S., Trainer, M., Fehsenfeld, F. C., Atlas, E. L., Donnelly, S. G., Stroud, V., and Lueb, A.: Volatile organic compounds composition of merged and aged forest fire plumes from Alaska and western Canada, J. Geophys. Res.-Atmos., 111, D10303, doi:10.1029/2005JD006175, 2006.

de Gouw, J. A., Middlebrook, A. M., Warneke, C., Ahmadov, R., Atlas, E. L., Bahreini, R., Blake, D. R., Brock, C. A., Brioude, J., Fahey, D. W., Fehsenfeld, F. C., Holloway, J. S., Le Henaff, M., Lueb, R. A., McKeen, S. A., Meagher, J. F., Murphy, D. M., Paris, C., Parrish, D. D., Perring, A. E., Pollack, I. B., Ravishankara, A. R., Robinson, A. L., Ryerson, T. B., Schwarz, J. P., Spackman, J. R., Srinivasan, A., and Watts, L. A.: Organic Aerosol Formation Downwind from the Deepwater Horizon Oil Spill, Science, 331, 1295-1299, 10.1126/science.1200320, 2011.

DeCarlo, P. F., Dunlea, E. J., Kimmel, J. R., Aiken, A. C., Sueper, D., Crounse, J., Wennberg, P. O., Emmons, L., Shinozuka, Y., Clarke, A., Zhou, J., Tomlinson, J., Collins, D. R., Knapp, D., Weinheimer, A. J., Montzka, D. D., Campos, T., and Jimenez, J. L.: Fast airborne aerosol size and chemistry measurements above Mexico City and Central Mexico during the MILAGRO campaign, Atmos. Chem. Phys., 8, 4027-4048, doi:10.5194/acp8-4027-2008, 2008.

Donahue, N. M., Robinson, A. L., Stanier, C. O., and Pandis, S. N.: Coupled partitioning, dilution, and chemical aging of semivolatile organics, Environ. Sci. Technol., 40, 02635-02643, doi:10.1021/es052297c, 2006.

Dunlea, E. J., DeCarlo, P. F., Aiken, A. C., Kimmel, J. R., Peltier, R. E., Weber, R. J., Tomlinson, J., Collins, D. R., Shinozuka, Y., McNaughton, C. S., Howell, S. G., Clarke, A. D., Emmons, L. K., Apel, E. C., Pfister, G. G., van Donkelaar, A., Martin, R. V., Millet, D. B., Heald, C. L., and Jimenez, J. L.: Evolution of Asian aerosols during transpacific transport in INTEX-B, Atmos. Chem. Phys., 9, 7257-7287, doi:10.5194/acp-9-7257-2009, 2009.

Eyring, V., Kohler, H. W., Lauer, A., and Lemper, B.: Emissions from international shipping: 2. Impact of future technologies on scenarios until 2050, J. Geophys. Res.-Atmos., 110, 18, D17306 doi:10.1029/2004jd005620, 2005a.

Eyring, V., Kohler, H. W., van Aardenne, J., and Lauer, A.: Emissions from international shipping: 1. The last 50 years, J. Geophys. Res.-Atmos., 110, 12, D17305, doi:10.1029/2004jd005619, 2005b.
Fairlie, T. D., Jacob, D. J., and Park, R. J.: The impact of transpacific transport of mineral dust in the United States, Atmos. Environ., 41, 1251-1266, 2007.

Farina, S. C., Adams, P. J., and Pandis, S. N.: Modeling global secondary organic aerosol formation and processing with the volatility basis set: Implications for anthropogenic secondary organic aerosol, J. Geophys. Res.-Biogeosci., 115, D09202, doi:10.1029/2009jd013046, 2010.

Fisher, J. A., Jacob, D. J., Wang, Q., Bahreini, R., Carouge, C. C., Cubison, M. J., Dibb, J. E., Diehl, T., Jimenez, J. L., Leibensperger, E. M., Meinders, M. B. J., Pye, H. O. T., Quinn, P. K., Sharma, S., van Donkelaar, A., and Yantosca, R. M.: Sources, distribution, and acidity of sulfate-ammonium aerosol in the Arctic in winter-spring, Atmos. Environ., 45, 7301-7318, doi:10.1016/j.atmosenv.2011.08.030, 2011.

Fu, T. M., Jacob, D. J., Wittrock, F., Burrows, J. P., Vrekoussis, M., and Henze, D. K.: Global budgets of atmospheric glyoxal and methylglyoxal, and implications for formation of secondary organic aerosols, J. Geophys. Res.-Atmos., 113, 17, D15303, doi:10.1029/2007jd009505, 2008.

Fu, T. M., Jacob, D. J., and Heald, C. L.: Aqueous-phase reactive uptake of dicarbonyls as a source of organic aerosol over eastern North America, Atmos. Environ., 43, 1814-1822, doi:10.1016/j.atmosenv.2008.12.029, 2009.

Fu, T.-M., Cao, J. J., Zhang, X. Y., Lee, S. C., Zhang, Q., Han, Y. M., Qu, W. J., Han, Z., Zhang, R., Wang, Y. X., Chen, D., and Henze, D. K.: Carbonaceous aerosols in China: topdown constraints on primary sources and estimation of secondary contribution, Atmos. Chem. Phys. Discuss., 11, 28219-28272, doi:10.5194/acpd-11-28219-2011, 2011.

George, I. J., Slowik, J., and Abbatt, J. P. D.: Chemical aging of ambient organic aerosol from heterogeneous reaction with hydroxyl radicals, Geophys. Res. Lett., 35, 5, L13811, doi:10.1029/2008g1033884, 2008.

Goldstein, A. H. and Galbally, I. E.: Known and unexplored organic constituents in the earth's atmosphere, Environ. Sci. Technol., 41, 1514-1521, 2007.

Grieshop, A. P., Logue, J. M., Donahue, N. M., and Robinson, A. L.: Laboratory investigation of photochemical oxidation of organic aerosol from wood fires 1: measurement and simulation of organic aerosol evolution, Atmos. Chem. Phys., 9, 1263-1277, doi:10.5194/acp-9-1263-2009, 2009.

Guenther, A., Karl, T., Harley, P., Wiedinmyer, C., Palmer, P. I., and Geron, C.: Estimates of global terrestrial isoprene emissions using MEGAN (Model of Emissions of Gases and Aerosols from Nature), Atmos. Chem. Phys., 6, 3181-3210, doi:10.5194/acp-63181-2006, 2006.

Hallquist, M., Wenger, J. C., Baltensperger, U., Rudich, Y., Simpson, D., Claeys, M., Dommen, J., Donahue, N. M., George, C., Goldstein, A. H., Hamilton, J. F., Herrmann, H., Hoffmann, T., Iinuma, Y., Jang, M., Jenkin, M. E., Jimenez, J. L., Kiendler-Scharr, A., Maenhaut, W., McFiggans, G., Mentel, Th. F., Monod, A., Prvt, A. S. H., Seinfeld, J. H., Surratt, J. D., Szmigielski, R., and Wildt, J.: The formation, properties and impact of secondary organic aerosol: current and emerging issues, Atmos. Chem. Phys., 9, 5155-5236, doi:10.5194/acp-95155-2009, 2009.

Hawkins, L. N., Russell, L. M., Covert, D. S., Quinn, P. K., and Bates, T. S.: Carboxylic acids, sulfates, and organosulfates in 
processed continental organic aerosol over the southeast Pacific Ocean during VOCALS-REx 2008, J. Geophys. Res.-Atmos., 115, 16, D13201, doi:10.1029/2009jd013276, 2010.

Heald, C. L., Jacob, D. J., Park, R. J., Russell, L. M., Huebert, B. J., Seinfeld, J. H., Liao, H., and Weber, R. J.: A large organic aerosol source in the free troposphere missing from current models, Geophys. Res. Lett., 32, L18809, doi:10.1029/2005GL023831, 2005.

Heald, C. L., Jacob, D. J., Turquety, S., Hudman, R. C., Weber, R. J., Sullivan, A. P., Peltier, R. E., Atlas, E. L., de Gouw, J. A., Warneke, C., Holloway, J. S., Neuman, J. A., Flocke, F. M., and Seinfeld, J. H.: Concentrations and sources of organic carbon aerosols in the free troposphere over North America, J. Geophys. Res.-Atmos., 111, D23S47, doi:10.1029/2006JD007705, 2006.

Heald, C. L., Ridley, D. A., Kreidenweis, S. M., and Drury, E. E.: Satellite observations cap the atmospheric organic aerosol budget, Geophys. Res. Lett., 37, 5, L24808 doi:10.1029/2010g1045095, 2010.

Hennigan, C. J., Bergin, M. H., Russell, A. G., Nenes, A., and Weber, R. J.: Gas/particle partitioning of water-soluble organic aerosol in Atlanta, Atmos. Chem. Phys., 9, 3613-3628, doi:10.5194/acp-9-3613-2009, 2009.

Henze, D. K., Seinfeld, J. H., Ng, N. L., Kroll, J. H., Fu, T.-M., Jacob, D. J., and Heald, C. L.: Global modeling of secondary organic aerosol formation from aromatic hydrocarbons: highvs. low-yield pathways, Atmos. Chem. Phys., 8, 2405-2420, doi:10.5194/acp-8-2405-2008, 2008.

Hodzic, A., Jimenez, J. L., Madronich, S., Aiken, A. C., Bessagnet, B., Curci, G., Fast, J., Lamarque, J.-F., Onasch, T. B., Roux, G., Schauer, J. J., Stone, E. A., and Ulbrich, I. M.: Modeling organic aerosols during MILAGRO: importance of biogenic secondary organic aerosols, Atmos. Chem. Phys., 9, 6949-6981, doi:10.5194/acp-9-6949-2009, 2009.

Hodzic, A., Jimenez, J. L., Madronich, S., Canagaratna, M. R., DeCarlo, P. F., Kleinman, L., and Fast, J.: Modeling organic aerosols in a megacity: potential contribution of semi-volatile and intermediate volatility primary organic compounds to secondary organic aerosol formation, Atmos. Chem. Phys., 10, 5491-5514, doi:10.5194/acp-10-5491-2010, 2010.

Huebert, B., Bertram, T., Kline, J., Howell, S., Eatough, D., and Blomquist, B.: Measurements of organic and elemental carbon in Asian outflow during ACE-Asia from the NSF/NCAR C-130, J. Geophys. Res.-Atmos., 109, 17, D19s11 doi:10.1029/2004jd004700, 2004.

Iinuma, Y., Böge, O., Gnauk, T., and Herrmann, H.: Aerosolchamber study of the $\alpha$-pinene $/ \mathrm{O}_{3}$ reaction: influence of particle acidity on aerosol yields and products, Atmos. Environ., 38, 761-773, 2004.

Jathar, S. H., Farina, S. C., Robinson, A. L., and Adams, P. J.: The influence of semi-volatile and reactive primary emissions on the abundance and properties of global organic aerosol, Atmos. Chem. Phys., 11, 7727-7746, doi:10.5194/acp-11-77272011, 2011.

Jayne, J. T., Leard, D. C., Zhang, X. F., Davidovits, P., Smith, K. A., Kolb, C. E., and Worsnop, D. R.: Development of an aerosol mass spectrometer for size and composition analysis of submicron particles, Aerosol Sci. Technol., 33, 49-70, 2000.

Jimenez, J. L., Canagaratna, M. R., Donahue, N. M., Prevot, A. S. H., Zhang, Q., Kroll, J. H., DeCarlo, P. F., Allan, J. D., Coe,
H., Ng, N. L., Aiken, A. C., Docherty, K. S., Ulbrich, I. M., Grieshop, A. P., Robinson, A. L., Duplissy, J., Smith, J. D., Wilson, K. R., Lanz, V. A., Hueglin, C., Sun, Y. L., Tian, J., Laaksonen, A., Raatikainen, T., Rautiainen, J., Vaattovaara, P., Ehn, M., Kulmala, M., Tomlinson, J. M., Collins, D. R., Cubison, M. J., Dunlea, E. J., Huffman, J. A., Onasch, T. B., Alfarra, M. R., Williams, P. I., Bower, K., Kondo, Y., Schneider, J., Drewnick, F., Borrmann, S., Weimer, S., Demerjian, K., Salcedo, D., Cottrell, L., Griffin, R., Takami, A., Miyoshi, T., Hatakeyama, S., Shimono, A., Sun, J. Y., Zhang, Y. M., Dzepina, K., Kimmel, J. R., Sueper, D., Jayne, J. T., Herndon, S. C., Trimborn, A. M., Williams, L. R., Wood, E. C., Middlebrook, A. M., Kolb, C. E., Baltensperger, U., and Worsnop, D. R.: Evolution of Organic Aerosols in the Atmosphere, Science, 326, 1525-1529, 10.1126/science.1180353, 2009.

Johnson, D., Utembe, S. R., Jenkin, M. E., Derwent, R. G., Hayman, G. D., Alfarra, M. R., Coe, H., and McFiggans, G.: Simulating regional scale secondary organic aerosol formation during the TORCH 2003 campaign in the southern UK, Atmos. Chem. Phys., 6, 403-418, doi:10.5194/acp-6-403-2006, 2006.

Karl, T., Apel, E., Hodzic, A., Riemer, D. D., Blake, D. R., and Wiedinmyer, C.: Emissions of volatile organic compounds inferred from airborne flux measurements over a megacity, Atmos. Chem. Phys., 9, 271-285, doi:10.5194/acp-9-271-2009, 2009.

Kleinman, L. I., Springston, S. R., Daum, P. H., Lee, Y.-N., Nunnermacker, L. J., Senum, G. I., Wang, J., Weinstein-Lloyd, J., Alexander, M. L., Hubbe, J., Ortega, J., Canagaratna, M. R., and Jayne, J.: The time evolution of aerosol composition over the Mexico City plateau, Atmos. Chem. Phys., 8, 1559-1575, doi:10.5194/acp-8-1559-2008, 2008.

Kroll, J. H., Ng, N. L., Murphy, S. M., Flagan, R. C., and Seinfeld, J. H.: Secondary organic aerosol formation from isoprene photooxidation under high-NOx conditions, Geophys. Res. Lett., 32, L18808, doi:10.1029/2005GL023637, 2005.

Kroll, J. H., Chan, A. W. H., Ng, N. L., Flagan, R. C., and Seinfeld, J. H.: Reactions of semivolatile organics and their effects on secondary organic aerosol formation, Environ. Sci. Technol., 41, 3545-3550, 2007.

Kroll, J. H., Smith, J. D., Che, D. L., Kessler, S. H., Worsnop, D. R., and Wilson, K. R.: Measurement of fragmentation and functionalization pathways in the heterogeneous oxidation of oxidized organic aerosol, Phys. Chem. Chem. Phys., 11, 8005-8014, 2009.

Kroll, J. H., Donahue, N. M., Jimenez, J. L., Kessler, S. H., Canagaratna, M. R., Wilson, K. R., Smith, J. D., Bluhm, H., Mysak, E. R., Kolb, C. E., and Worsnop, D. R.: Carbon oxidation state and the chemistry of atmospheric organic aerosol, Nat. Chem., 3, 133-139, 2011.

Kuhns, H., Knipping, E. M., and Vukovich, J. M.: Development of a United States-Mexico emissions inventory for the Big Bend Regional Aerosol and Visibility Observational (BRAVO) Study, J. Air Waste Manage. Assoc., 55, 677-692, 2005.

Kwan, A. J., Crounse, J. D., Clarke, A. D., Shinozuka, Y., Anderson, B. E., Crawford, J. H., Avery, M. A., McNaughton, C. S., Brune, W. H., Singh, H. B., and Wennberg, P. O.: On the flux of oxygenated volatile organic compounds from organic aerosol oxidation, Geophys. Res. Lett., 33, L15815, doi:10.1029/2006GL026144, 2006.

Lane, T. E., Donahue, N. M., and Pandis, S. N.: Simulating secondary organic aerosol formation using the volatility basis-set 
approach in a chemical transport model, Atmos. Environ., 42, 7439-7451, doi:10.1016/j.atmosenv.2008.06.026, 2008.

Lapina, K., Heald, C. L., Spracklen, D. V., Arnold, S. R., Allan, J. D., Coe, H., McFiggans, G., Zorn, S. R., Drewnick, F., Bates, T. S., Hawkins, L. N., Russell, L. M., Smirnov, A., O’Dowd, C. D., and Hind, A. J.: Investigating organic aerosol loading in the remote marine environment, Atmos. Chem. Phys., 11, 88478860, doi:10.5194/acp-11-8847-2011, 2011.

Lewis, A. C., Evans, M. J., Methven, J., Watson, N., Lee, J. D., Hopkins, J. R., Purvis, R. M., Arnold, S. R., McQuaid, J. B., Whalley, L. K., Pilling, M. J., Heard, D. E., Monks, P. S., Parker, A. E., Reeves, C. E., Oram, D. E., Mills, G., Bandy, B. J., Stewart, D., Coe, H., Williams, P., and Crosier, J.: Chemical composition observed over the mid-Atlantic and the detection of pollution signatures far from source regions, J. Geophys. Res.-Atmos., 112, D10S39, doi:10.1029/2006JD007584, 2007.

Liao, H., Henze, D. K., Seinfeld, J. H., Wu, S. L., and Mickley, L. J.: Biogenic secondary organic aerosol over the United States: Comparison of climatological simulations with observations, J. Geophys. Res.-Atmos., 112, doi:10.1029/2006JD007813, 2007.

Lim, H. J., Carlton, A. G., and Turpin, B. J.: Isoprene forms secondary organic aerosol through cloud processing: Model simulations, Environ. Sci. Technol., 39, 4441-4446, 2005.

Lim, Y. B. and Ziemann, P. J.: Chemistry of Secondary Organic Aerosol Formation from $\mathrm{OH}$ Radical-Initiated Reactions of Linear, Branched, and Cyclic Alkanes in the Presence of NOx, Aerosol Sci. Technol., 43, 604-619, doi:10.1080/02786820902802567, 2009.

Liu, H. Y., Jacob, D. J., Bey, I., and Yantosca, R. M.: Constraints from $\mathrm{Pb}-210$ and $\mathrm{Be}-7$ on wet deposition and transport in a global three-dimensional chemical tracer model driven by assimilated meteorological fields, J. Geophys. Res.-Atmos., 106, 1210912128, 2001.

Mader, B. T., Flagan, R. C., and Seinfeld, J. H.: Airborne measurements of atmospheric carbonaceous aerosols during ACE-Asia, J. Geophys. Res.-Atmos., 107, 21, 4704, doi:10.1029/2002jd002221, 2002.

Maria, S. F., Russell, L. M., Turpin, B. J., and Porcja, R. J.: FTIR measurements of functional groups and organic mass in aerosol samples over the Caribbean, Atmos. Environ., 36, 5185-5196, 2002.

Maria, S. F., Russell, L. M., Turpin, B. J., Porcja, R. J., Campos, T. L., Weber, R. J., and Huebert, B. J.: Source signatures of carbon monoxide and organic functional groups in Asian Pacific Regional Aerosol Characterization Experiment (ACE-Asia) submicron aerosol types, J. Geophys. Res.-Atmos., 108, 8637, doi:8610.1029/2003JD003703, 2003.

Maria, S. F., Russell, L. M., Gilles, M. K., and Myneni, S. C. B.: Organic aerosol growth mechanisms and their climate-forcing implications, Science, 306, 1921-1924, 2004.

Molina, M. J., Ivanov, A. V., Trakhtenberg, S., and Molina, L. T.: Atmospheric evolution of organic aerosol, Geophys. Res. Lett., 31, L22104, doi:10.1029/2004GL020910, 2004.

Morgan, W. T., Allan, J. D., Bower, K. N., Highwood, E. J., Liu, D., McMeeking, G. R., Northway, M. J., Williams, P. I., Krejci, R., and Coe, H.: Airborne measurements of the spatial distribution of aerosol chemical composition across Europe and evolution of the organic fraction, Atmos. Chem. Phys., 10, 4065-4083, doi:10.5194/acp-10-4065-2010, 2010.
Murphy, B. N. and Pandis, S. N.: Simulating the Formation of Semivolatile Primary and Secondary Organic Aerosol in a Regional Chemical Transport Model, Environ. Sci. Technol., 43, 4722-4728, doi:10.1021/es803168a, 2009.

Murphy, J. G., Oram, D. E., and Reeves, C. E.: Measurements of volatile organic compounds over West Africa, Atmos. Chem. Phys., 10, 5281-5294, doi:10.5194/acp-10-5281-2010, 2010.

Ng, N. L., Chhabra, P. S., Chan, A. W. H., Surratt, J. D., Kroll, J. H., Kwan, A. J., McCabe, D. C., Wennberg, P. O., Sorooshian, A., Murphy, S. M., Dalleska, N. F., Flagan, R. C., and Seinfeld, J. H.: Effect of $\mathrm{NO}_{\mathrm{x}}$ level on secondary organic aerosol (SOA) formation from the photooxidation of terpenes, Atmos. Chem. Phys., 7, 5159-5174, doi:10.5194/acp-7-5159-2007, 2007a.

Ng, N. L., Kroll, J. H., Chan, A. W. H., Chhabra, P. S., Flagan, R. C., and Seinfeld, J. H.: Secondary organic aerosol formation from m-xylene, toluene, and benzene, Atmos. Chem. Phys., 7, 3909-3922, doi:10.5194/acp-7-3909-2007, 2007b.

Olivier, J. G. J., Berdowski, J. J. M., Peters, J. A. H. W., Bakker, J., Visschedijk, A. J. H., and J.-P.J.Bloos: Applications of EDGAR Including a description of EDGAR 3.0: reference database with trend data for 1970-1995 Natl. Inst. of Public Health and Environ., Bilthoven, Netherlands, 2001.

Pankow, J. F.: Organic particulate material levels in the atmosphere: Conditions favoring sensitivity to varying relative humidity and temperature, Proc. Natl. Acad. Sci. U. S. A., 107, 6682-6686, doi:10.1073/pnas.1001043107, 2010.

Park, R. J., Jacob, D. J., Chin, M., and Martin, R. V.: Sources of carbonaceous aerosols over the United States and implications for natural visibility, J. Geophys. Res.-Atmos., 108, doi:10.1029/2002JD003190, 4355, 2003.

Park, R. J., Jacob, D. J., Field, B. D., Yantosca, R. M., and Chin, M.: Natural and transboundary pollution influences on sulfate-nitrate-ammonium aerosols in the United States: Implications for policy, J. Geophys. Res.-Atmos., 109, D15204, doi:10.1029/2003JD004473, 2004.

Peltier, R. E., Sullivan, A. P., Weber, R. J., Brock, C. A., Wollny, A. G., Holloway, J. S., de Gouw, J. A., and Warneke, C.: Fine aerosol bulk composition measured on WP-3D research aircraft in vicinity of the Northeastern United States - results from NEAQS, Atmos. Chem. Phys., 7, 3231-3247, doi:10.5194/acp7-3231-2007, 2007.

Pye, H. O. T. and Seinfeld, J. H.: A global perspective on aerosol from low-volatility organic compounds, Atmos. Chem. Phys., 10, 4377-4401, doi:10.5194/acp-10-4377-2010, 2010.

Rastigejev, Y., Park, R., Brenner, M. P., and Jacob, D. J.: Resolving intercontinental pollution plumes in global models of atmospheric transport, J. Geophys. Res.-Atmos., 115, 11, D02302 doi:10.1029/2009jd012568, 2010.

Reeves, C. E., Formenti, P., Afif, C., Ancellet, G., Atti, J.-L., Bechara, J., Borbon, A., Cairo, F., Coe, H., Crumeyrolle, S., Fierli, F., Flamant, C., Gomes, L., Hamburger, T., Jambert, C., Law, K. S., Mari, C., Jones, R. L., Matsuki, A., Mead, M. I., Methven, J., Mills, G. P., Minikin, A., Murphy, J. G., Nielsen, J. K., Oram, D. E., Parker, D. J., Richter, A., Schlager, H., Schwarzenboeck, A., and Thouret, V.: Chemical and aerosol characterisation of the troposphere over West Africa during the monsoon period as part of AMMA, Atmos. Chem. Phys., 10, 7575-7601, doi:10.5194/acp-10-7575-2010, 2010.

Robinson, A. L., Donahue, N. M., Shrivastava, M. K., Weitkamp, 
E. A., Sage, A. M., Grieshop, A. P., Lane, T. E., Pierce, J. R., and Pandis, S. N.: Rethinking organic aerosols: Semivolatile emissions and photochemical aging, Science, 315, 1259-1262, 2007.

Robinson, N. H., Hamilton, J. F., Allan, J. D., Langford, B., Oram, D. E., Chen, Q., Docherty, K., Farmer, D. K., Jimenez, J. L., Ward, M. W., Hewitt, C. N., Barley, M. H., Jenkin, M. E., Rickard, A. R., Martin, S. T., McFiggans, G., and Coe, H.: Evidence for a significant proportion of Secondary Organic Aerosol from isoprene above a maritime tropical forest, Atmos. Chem. Phys., 11, 1039-1050, doi:10.5194/acp-11-1039-2011, 2011.

Russell, L. M., Bahadur, R., and Ziemann, P. J.: Identifying organic aerosol sources by comparing functional group composition in chamber and atmospheric particles, Proc. Natl. Acad. Sci. U. S. A., 108, 3516-3521, doi:10.1073/pnas.1006461108, 2011.

Shilling, J. E., Chen, Q., King, S. M., Rosenoern, T., Kroll, J. H., Worsnop, D. R., McKinney, K. A., and Martin, S. T.: Particle mass yield in secondary organic aerosol formed by the dark ozonolysis of $\alpha$-pinene, Atmos. Chem. Phys., 8, 2073-2088, doi:10.5194/acp-8-2073-2008, 2008.

Singh, H. B., Anderson, B. E., Brune, W. H., Cai, C., Cohen, R. C., Crawford, J. H., Cubison, M. J., Czech, E. P., Emmons, L., Fuelberg, H. E., Huey, G., Jacob, D. J., Jimenez, J. L., Kaduwela, A., Kondo, Y., Mao, J., Olson, J. R., Sachse, G. W., Vay, S. A., Weinheimer, A., Wennberg, P. O., and Wisthaler, A.: Pollution influences on atmospheric composition and chemistry at high northern latitudes: Boreal and California forest fire emissions, Atmos. Environ., 44, 4553-4564, doi:10.1016/j.atmosenv.2010.08.026, 2011.

Slowik, J. G., Stroud, C., Bottenheim, J. W., Brickell, P. C., Chang, R. Y.-W., Liggio, J., Makar, P. A., Martin, R. V., Moran, M. D., Shantz, N. C., Sjostedt, S. J., van Donkelaar, A., Vlasenko, A., Wiebe, H. A., Xia, A. G., Zhang, J., Leaitch, W. R., and Abbatt, J. P. D.: Characterization of a large biogenic secondary organic aerosol event from eastern Canadian forests, Atmos. Chem. Phys., 10, 2825-2845, doi:10.5194/acp-10-2825-2010, 2010.

Smith, J. D., Kroll, J. H., Cappa, C. D., Che, D. L., Liu, C. L., Ahmed, M., Leone, S. R., Worsnop, D. R., and Wilson, K. R.: The heterogeneous reaction of hydroxyl radicals with submicron squalane particles: a model system for understanding the oxidative aging of ambient aerosols, Atmos. Chem. Phys., 9, 3209-3222, doi:10.5194/acp-9-3209-2009, 2009.

Sorooshian, A., Lu, M. L., Brechtel, F. J., Jonsson, H., Feingold, G., Flagan, R. C., and Seinfeld, J. H.: On the Source of Organic Acid Aerosol Layers above Clouds, Environ. Sci. Technol., 41, 4647-4654, 2007a.

Sorooshian, A., Ng, N. L., Chan, A. W. H., Feingold, G., Flagan, R. C., and Seinfeld, J. H.: Particulate organic acids and overall water-soluble aerosol composition measurements from the 2006 Gulf of Mexico Atmospheric Composition and Climate Study (GoMACCS), J. Geophys. Res.-Atmos., 112, D13201, doi:13210.11029/12007JD008537, 2007b.

Sorooshian, A., Murphy, S. M., Hersey, S., Bahreini, R., Jonsson, H., Flagan, R. C., and Seinfeld, J. H.: Constraining the contribution of organic acids and AMS m/z 44 to the organic aerosol budget: On the importance of meteorology, aerosol hygroscopicity, and region, Geophys. Res. Lett., 37, 5, L21807, doi:10.1029/2010g1044951, 2010.

Spracklen, D. V., Jimenez, J. L., Carslaw, K. S., Worsnop, D. R., Evans, M. J., Mann, G. W., Zhang, Q., Canagaratna, M. R.,
Allan, J., Coe, H., McFiggans, G., Rap, A., and Forster, P.: Aerosol mass spectrometer constraint on the global secondary organic aerosol budget, Atmos. Chem. Phys., 11, 12109-12136, doi:10.5194/acp-11-12109-2011, 2011.

Streets, D. G., Zhang, Q., Wang, L. T., He, K. B., Hao, J. M., Wu, Y., Tang, Y. H., and Carmichael, G. R.: Revisiting China's $\mathrm{CO}$ emissions after the Transport and Chemical Evolution over the Pacific (TRACE-P) mission: Synthesis of inventories, atmospheric modeling, and observations, J. Geophys. Res.-Atmos., 111, doi:10.1029/2006JD007118, D14306, 2006.

Sullivan, A. P., Peltier, R. E., Brock, C. A., de Gouw, J. A., Holloway, J. S., Warneke, C., Wollny, A. G., and Weber, R. J.: Airborne measurements of carbonaceous aerosol soluble in water over northeastern United States: Method development and an investigation into water-soluble organic carbon sources, J. Geophys. Res.-Atmos., 111, D23S46, doi:10.1029/2006JD007072, 2006.

Surratt, J. D., Lewandowski, M., Offenberg, J. H., Jaoui, M., Kleindienst, T. E., Edney, E. O., and Seinfeld, J. H.: Effect of acidity on secondary organic aerosol formation from isoprene, Environ. Sci. Technol., 41, 5363-5369, 2007.

Turpin, B. J., and Lim, H. J.: Species contributions to PM2.5 mass concentrations: Revisiting common assumptions for estimating organic mass, Aerosol Sci. Technol., 35, 602-610, 2001.

van der Werf, G. R., Randerson, J. T., Giglio, L., Collatz, G. J., Kasibhatla, P. S., and Arellano Jr., A. F.: Interannual variability in global biomass burning emissions from 1997 to 2004, Atmos. Chem. Phys., 6, 3423-3441, doi:10.5194/acp-6-3423-2006, 2006.

van Donkelaar, A., Martin, R. V., Park, R. J., Heald, C. L., Fu, T. M., Liao, H., and Guenther, A.: Model evidence for a significant source of secondary organic aerosol from isoprene, Atmos. Environ., 41, 1267-1274, 2007.

Vestreng, V. and Klein, H.: Emission data reported to UNECE/EMEP: quality assurance and trend analysis \& presentation of WebDab., Norwegian Meteorological Institute, Oslo, Norway, 2002.

Volkamer, R., Jimenez, J. L., San Martini, F., Dzepina, K., Zhang, Q., Salcedo, D., Molina, L. T., Worsnop, D. R., and Molina, M. J.: Secondary organic aerosol formation from anthropogenic air pollution: Rapid and higher than expected, Geophys. Res. Lett., 33, L17811, doi:10.1029/2006GL026899, 2006.

Volkamer, R., Martini, F. S., Molina, L. T., Salcedo, D., Jimenez, J. L., and Molina, M. J.: A missing sink for gas-phase glyoxal in Mexico City: Formation of secondary organic aerosol, Geophys. Res. Lett., 34, L19807, doi:10.1029/2007GL030752, 2007.

Volkamer, R., Ziemann, P. J., and Molina, M. J.: Secondary Organic Aerosol Formation from Acetylene $\left(\mathrm{C}_{2} \mathrm{H}_{2}\right)$ : seed effect on SOA yields due to organic photochemistry in the aerosol aqueous phase, Atmos. Chem. Phys., 9, 1907-1928, doi:10.5194/acp9-1907-2009, 2009.

Wang, C., Corbett, J. J., and Firestone, J.: Improving spatial representation of global ship emissions inventories, Environ. Sci. Technol., 42, 193-199, doi:10.1021/es0700799, 2008.

Wang, Q., Jacob, D. J., Fisher, J. A., Mao, J., Leibensperger, E. M., Carouge, C. C., Le Sager, P., Kondo, Y., Jimenez, J. L., Cubison, M. J., and Doherty, S. J.: Sources of carbonaceous aerosols and deposited black carbon in the Arctic in winter-spring: implications for radiative forcing, Atmos. Chem. Phys., 11, 12453- 
12473, doi:10.5194/acp-11-12453-2011, 2011.

Wang, Y. H., Jacob, D. J., and Logan, J. A.: Global simulation of tropospheric O-3-NOx-hydrocarbon chemistry 1. Model formulation, J. Geophys. Res.-Atmos., 103, 10713-10725, 1998.

Warneke, C., de Gouw, J. A., Stohl, A., Cooper, O. R., Goldan, P. D., Kuster, W. C., Holloway, J. S., Williams, E. J., Lerner, B. M., McKeen, S. A., Trainer, M., Fehsenfeld, F. C., Atlas, E. L., Donnelly, S. G., Stroud, V., Lueb, A., and Kato, S.: Biomass burning and anthropogenic sources of $\mathrm{CO}$ over New England in the summer 2004, J. Geophys. Res.-Atmos., 111, 13, D23s15, doi:10.1029/2005jd006878, 2006.

Wesely, M. L.: Parameterization of surface resistances to gaseous dry deposition in regional scale numerical models, Atmos. Environ., 23, 1293-1304, 1989.
Yevich, R. and Logan, J. A.: An assessment of biofuel use and burning of agricultural waste in the developing world, Glob. Biogeochem. Cy., 17, doi:10.1029/2002GB001952, 2003.

Zhang, Q., Jimenez, J., Canagaratna, M. R., Allan, J. D., Coe, H., Ulbrich, I., Alfarra, M. R., Takami, A., Middlebrook, A. M., Sun, Y. L., Dzepina, K., Dunlea, E., Docherty, K., DeCarlo, P. F., Salcedo, D., Onasch, T. B., Jayne, J., Miyoshi, T., Shimono, A., Hatakeyama, S., Takegawa, N., Kondo, Y., Schneider, J., Drewnick, F., Borrmann, S., Weimer, S., Demerjian, K., Williams, P., Bower, K., Bahreini, R., Cottrell, L., Griffin, R. J., Rautiainen, J., Sun, J. Y., Zhang, Y. M., and Worsnop, D. R.: Ubiquity and dominance of oxygenated species in organic aerosols in anthropogenicallyinfluenced Northern Hemisphere midlatitudes, Geophys. Res. Lett., 34, doi:10.1029/2007GL029979, 2007. 